\title{
Linking equity, power, and stakeholders' roles in relation to ecosystem services
}

\author{
Améline Vallet $^{1,2}$, Bruno Locatelli $^{3,4}$, Harold Levrel $^{2}$, Nicolas Dendoncker $^{5}$, Cecile Barnaud $^{6}$ and Yésica Quispe Conde $^{7}$
}

\begin{abstract}
The issues of power and equity are gaining attention in research on ecosystem services (ESs). Stakeholders benefiting from ESs are not necessarily able or authorized to participate in ES management. Thus, we have proposed an analytical framework to identify and qualify stakeholders' roles in relation to ES flows. Building on existing frameworks in the ES literature, we aimed to unravel the different direct and indirect management contributions to ES flows and link them to ES benefits. Direct management targets the functioning of ecosystems, the flows of services, and the benefits received by society, whereas indirect management facilitates, controls, or restricts the activities of direct managers. We applied this framework to the Mariño watershed (Peru) to describe stakeholders' roles using a set of $8 \mathrm{ESs}$. We have discussed the implications of our findings in terms of equity and power distribution. We conducted faceto-face semistructured interviews with representatives of 52 watershed stakeholders to understand how they managed and benefited from ESs. We used statistical analysis (permutation tests) to detect significant differences in the number of received and managed ESs among stakeholder sectors, i.e., civil society, nongovernmental organizations (NGOs), business, and the public sector, and scales, from local to national levels. Indirect forms of ES management were more frequent than direct ones for all ESs. Water quantity, water quality, and agricultural production were managed by the largest number of stakeholder types. The differences in the number of stakeholder types benefiting from and managing ESs could result from intentional choices, e.g., preferences for local benefits. We also found clear differences in the identity of stakeholders who managed or benefited from ESs. Local stakeholders and the business sector benefited from a higher number of ESs, and public organizations and NGOs were most involved in ES management. More equitable governance of ESs should aim to integrate more diverse stakeholders into decision making. Further empirical research could use our framework to explore the factors determining stakeholders' roles and power distribution. There is a particular need to understand how rights, endowments, and entitlements, as well as spatial configuration, underpin inequities in different social and cultural contexts.
\end{abstract}

Key Words: adaptive comanagement; ecosystem management; ecosystem services governance; environmental justice; landscape sustainability; trade-off

\section{INTRODUCTION}

Ecosystem services (ESs), defined as the benefits that humans derive from ecosystems, contribute to the well-being of people in multiple ways. As ES benefits are heterogeneously distributed in society, with some stakeholders being able to influence how ESs are delivered to humans, ES governance is profoundly linked to issues of power and equity (Ernstson 2013, Berbés-Blázquez et al. 2016, Chaudhary et al. 2018). Stakeholders play different roles in the distribution of ESs or natural resources, as well as their management. For example, stakeholders with access or withdrawal rights are not necessarily authorized to manage landscapes or exclude other stakeholders (Schlager and Ostrom 1992). Because an unequal distribution of these roles may create conflicts among stakeholders, it is crucial to address power and equity issues for more sustainable, equitable, and resilient governance of ecosystems and their services (Howe et al. 2014, Turkelboom et al. 2018).

We understand governance as the structures and processes that enable collective action, decision making, and power sharing (Folke et al. 2005). We specifically focus on the "power to" influence the ES cascade, what we will simply call power in the following, and we do not take into account other forms of relational power considered in social and political sciences, such as domination, coercion, or authority that rather refer to "power over" other stakeholders (Pitkin 1972, Giddens 1979, Göhler 2009). We define power as the "ability to affect outcomes or get things done" (Brass and Burkhardt 1993:441). To influence ES delivery, stakeholders can accomplish different things all by themselves, e.g., managing the ecosystems that produce ESs, but they may also involve other people if they have power over them (Pitkin 1972). In the following, we investigate power distribution or imbalances, i.e., the differentiated capacity to influence the ES cascade or "power to," rather than the power relationships among stakeholders ("power over").

Power is related to different forms of equity, such as distribution equity, i.e., appropriate and fair distribution of goods or resources, also known as outcome justice; procedural equity, i.e., fair participation of stakeholders in public life and decision making, also known as process justice; and recognition equity, i.e., fair consideration of all individuals and their concerns, with or without direct participation (Cutter 1995, Schlosberg 2003). How power underpins inequities, how roles are established, and who should be involved in the management of ESs and natural resources are fundamental sustainability questions (Borrini-Feyerabend et al.

\footnotetext{
${ }^{1}$ Ecologie Systématique Evolution, AgroParisTech, CNRS, Université Paris-Sud, Université Paris-Saclay, Orsay, France, ${ }^{2} \mathrm{CIRED}$, AgroParisTech, Cirad, CNRS, EHESS, Ecole des Ponts ParisTech, Université Paris-Saclay, Nogent-sur-Marne, France, ${ }^{3}$ CIRAD, Forests and Societies, University of Montpellier, Montpellier, France, ${ }^{4}$ CIFOR, Lima, Peru, ${ }^{5}$ Department of Geography, Institute Life Earth and Environment, Transitions Institute, University of Namur, Belgium, ${ }^{6}$ DYNAFOR, Université de Toulouse, INPT, INRA, Toulouse, France, ${ }^{7}$ SUNASS Apurimac, Abancay, Apurimac, Peru
} 
Table 1. Comparison of existing ecosystem service (ES) management frameworks. We distinguish between direct and indirect ES management.

\begin{tabular}{|c|c|c|c|}
\hline Reference & Framework Focus & $\begin{array}{l}\text { Explicit Consideration } \\
\text { of ES Cascade Steps? }\end{array}$ & Roles of Different Stakeholders? \\
\hline \multicolumn{4}{|c|}{ Frameworks focusing on direct contributions: ES coproduction } \\
\hline Lele et al. (2013) & $\begin{array}{l}\text { Human agency in the form of labor and other forms of } \\
\text { capital }\end{array}$ & No & No \\
\hline Spangenberg et al. (2014) & $\begin{array}{l}\text { Social processes accompanying ES flows along the } \\
\text { cascade }\end{array}$ & Yes (several steps) & No \\
\hline Felipe-Lucia et al. (2015) & $\begin{array}{l}\text { Interactions among ESs and stakeholders that mediate } \\
\text { access to ESs }\end{array}$ & $\begin{array}{l}\text { Yes (supply vs. } \\
\text { demand) }\end{array}$ & $\begin{array}{l}\text { Yes (four types depending on } \\
\text { dependence and influence) }\end{array}$ \\
\hline Palomo et al. (2016) & Capital assets contributing to ES coproduction & No & No \\
\hline Fedele et al. (2017) & Mediating mechanisms and factors along the ES cascade & Yes (several steps) & No \\
\hline \multicolumn{4}{|c|}{ Frameworks focusing on indirect contributions to ES decision making } \\
\hline $\begin{array}{l}\text { Iniesta-Arandia et al. } \\
\text { (2014) }\end{array}$ & Analysis of stakeholders and stakeholder groups & No & Yes (managers vs. beneficiaries) \\
\hline Primmer et al. (2015) & $\begin{array}{l}\text { Different modes of governance that relate to the ES } \\
\text { cascade }\end{array}$ & Yes & No \\
\hline Turkelboom et al. (2018) & Impact of stakeholder choices on ES trade-offs & No & $\begin{array}{l}\text { Yes (influential users, } \\
\text { noninfluential users, context } \\
\text { setters) }\end{array}$ \\
\hline \multicolumn{4}{|c|}{ Frameworks focusing on direct and indirect forms of ES management } \\
\hline Barnaud et al. (2018) & Social interdependencies underlying ES dynamics & No & $\begin{array}{l}\text { Yes (beneficiaries, providers, } \\
\text { intermediary stakeholders) }\end{array}$ \\
\hline
\end{tabular}

2004, Adger et al. 2005, Armitage et al. 2009). Research gaps include the development of methods to better understand the different stakeholder roles and inequities in relation to ESs, as well as the mechanisms that underpin them (Sikor 2013, Barnaud et al. 2018, Chaudhary et al. 2018).

Previous ES studies have partially addressed these questions. On the one hand, empirical studies focus on either the distributive dimension of equity by analyzing the differentiated distribution of ES benefits across different groups of stakeholders (HorceaMilcu et al. 2016, Suwarno et al. 2016, Ishihara et al. 2017) or its procedural dimension by highlighting the unequal participation of stakeholders in ES decision-making processes (Ernstson et al. 2008, Alonso Roldán et al. 2015, Felipe-Lucia et al. 2015). Nevertheless, these empirical studies do not provide a comprehensive understanding of stakeholders' roles and influences over ES flows.

On the other hand, articles with more theoretical frameworks propose to conceptualize these roles in an integrated manner in conjunction with the ES cascade (Haines-Young and Potschin 2010). Some frameworks specifically focus on the direct contributions of different stakeholders to the production of ESs, i.e., ES coproduction, whereas others analyze stakeholders' indirect influence on ES decision making (Table 1). The concept of ES coproduction recognizes human agency in ES flows along the cascade: benefits do not automatically flow from ecosystems to human well-being, as they rather result from interactions between ecosystem processes, human labor, and different forms of capital (Goodwin 2003, Lele et al. 2013, Palomo et al. 2016). For example, water regulation by ecosystems often benefits society thanks to storage and transport technologies, e.g., dams and pipes. Similarly, provisioning services, e.g., food and wild plants, need to be gathered or harvested before being sold or consumed. These direct human interventions are only one facet of ES management, which can also be influenced indirectly by stakeholders participating in the decision-making processes or controlling, sanctioning, or incentivizing actions along the ES cascade (Iniesta-Arandia et al. 2014, Barnaud et al. 2018).

Most of the reviewed frameworks only consider one modality of ES management, either direct or indirect (Table 1). Only the framework of Barnaud et al. (2018) considers both, which led the authors to distinguish between two types of ES managers in addition to ES beneficiaries: providers, who coproduce or manage ESs through direct actions on ecosystems, and intermediary stakeholders, who indirectly influence ES decision making through interactions with ES providers and beneficiaries (Table 1). Another limitation of the reviewed frameworks is that they do not always unravel the different steps of the ES cascade at which ES management takes place. Only those focusing explicitly on ES coproduction usually do this (e.g., Spangenberg et al. 2014, Fedele et al. 2017). Finally, few of the listed frameworks have been applied and tested with empirical data (Iniesta-Arandia et al. 2014, Felipe-Lucia et al. 2015, Turkelboom et al. 2018).

We therefore aim to provide an analytical framework to better identify and qualify stakeholders' roles in relation to the ES cascade. We also propose a reproducible method to apply this framework to real-world situations to highlight the unequal distribution of roles in society. Our framework considers both the received ES, i.e., distributive equity, and the participation in ES management, i.e., procedural equity. Building on the existing literature, it provides a comprehensive approach to identify the different forms of ES management, direct and indirect, that occur at the different steps of the ES cascade and then link them to the amount of received ES benefits. This framework specifically addresses three questions: Who participates in ES management? How are ESs managed? How are benefits distributed among stakeholders? We apply our framework to the Mariño watershed 
Fig. 1. Analytical framework. Two forms of ecosystem service (ES) management, direct and indirect, can happen at three steps of the ES cascade: ecosystem, service, and use.

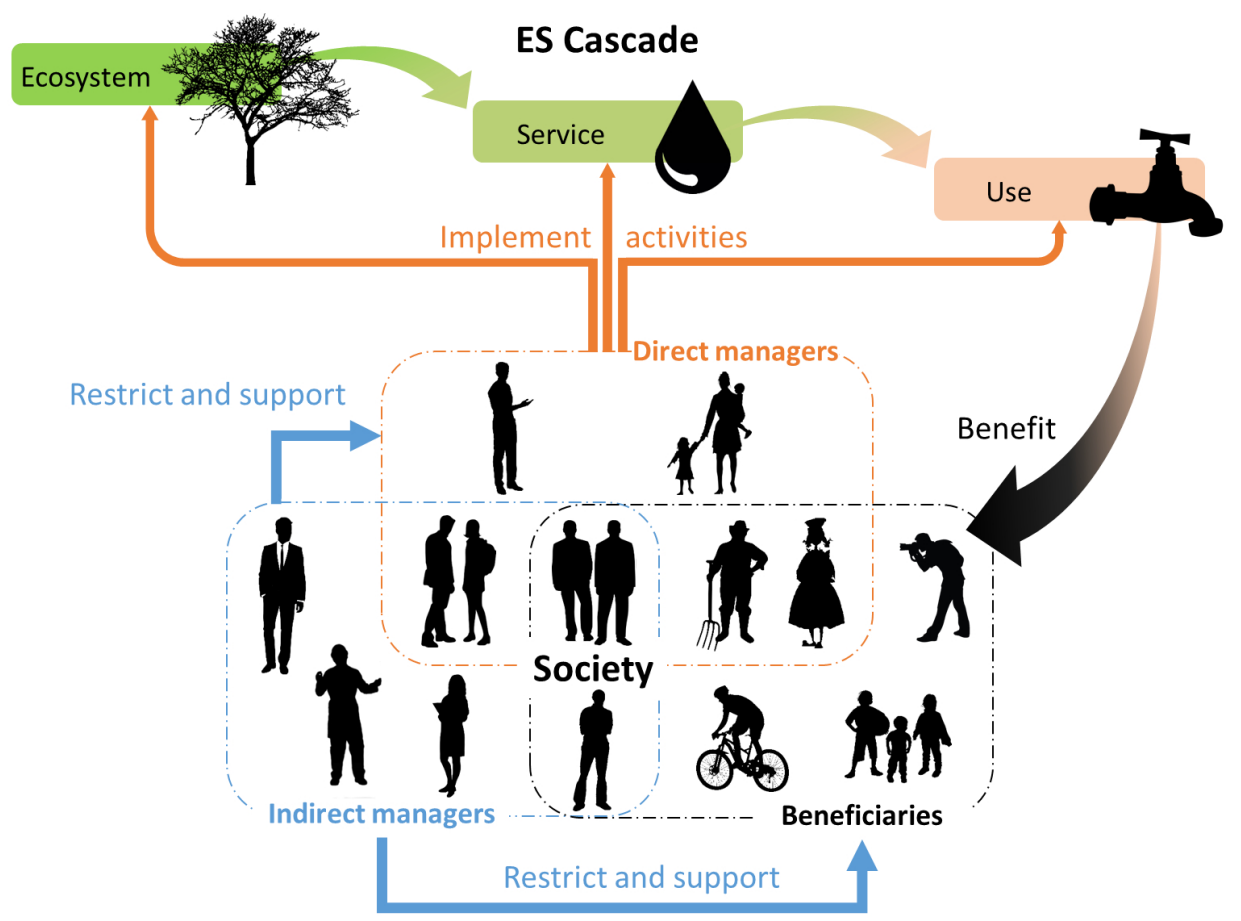

in Peru to describe stakeholders' roles using a set of eight ESs and discuss the implications of our findings in terms of equity and power.

\section{FRAMEWORK FOR IDENTIFYING STAKEHOLDERS' ROLES}

Our stakeholder-centered analytical framework considers two modalities of interactions with the ES cascade: (1) management activities contributing to ES flow and (2) benefits received by stakeholders (Fig. 1). To facilitate the application of the ES cascade in the real world, we consider a simplified version with only four steps: ecosystem, service, use, and benefit.

Following Freeman (1984:46), we define stakeholders as "any group or individual who can affect or is affected by the achievement" of some objectives. In relation to ES governance, stakeholders can be individuals, e.g., farmers and urban population, or groups of individuals, e.g., associations and agricultural cooperatives, as well as organizations, e.g., businesses, nongovernmental organizations (NGOs), and governments from local to national scales, which manage or benefit from ESs or both (Felipe-Lucia et al. 2015, Barnaud et al. 2018). Our framework explicitly recognizes the diversity of stakeholders at multiple scales with interrelations between nested scales (BorriniFeyerabend et al. 2004, Olsson et al. 2004, Folke et al. 2005). Stakeholders can interact with each other through power relationships (Barnaud et al. 2018), but these are beyond our scope, which focuses on stakeholders' capacity to manage and influence the ES cascade ("power to"), rather than the power exerted over people (Pitkin 1972, Giddens 1979, Göhler 2009).
Stakeholders have different rights (Schlager and Ostrom 1992) and entitlements (Sen 1984, Leach et al. 1999) regarding their access to ES benefits and participation in ES management. Rights are the particular actions that stakeholders are authorized to conduct and are derived from rules and institutions (Schlager and Ostrom 1992). Entitlements are the "set of alternative commodity bundles that a person can command in a society using the totality of rights and opportunities that he or she faces," i.e., his or her endowments (Sen 1984:497). Entitlements define stakeholders' capabilities, i.e., what people can do, to effectively benefit from and manage ESs (Sen 1984, Leach et al. 1999). The differentiation between rights and entitlements is responsible for both distributive and procedural inequities among stakeholders' groups (Mearns 1996, Leach et al. 1999, Borrini-Feyerabend et al. 2004). Stakeholders with high or diversified capabilities, resulting from either their rights or individual capital, generally have low dependence on ES benefits, because they have a broad range of alternatives to cope with any ES losses and can shift their strategies to secure their livelihoods (Scoones 1998, Ashley et al. 1999, Goodwin 2003). As some have noted, the entitlements and rights to benefit from or manage ESs might have spatially explicit dimensions (Yandle 2007, White and Costello 2011). For example, only the residents of a rural community may be allowed to use the nearby communal lands for grazing animals or collecting plants and fuelwood.

We define ES benefits as the contribution made to the material and spiritual well-being of an individual or to the mission of an organization, e.g., reduced operating costs, reduced asset losses caused by disasters, and increased income from ES usage fees. Benefits can be direct, e.g., food and medicinal plants, or indirect, 
Table 2. Different forms of ecosystem service (ES) management.

\begin{tabular}{|c|c|c|}
\hline $\begin{array}{l}\text { Management } \\
\text { Levels }\end{array}$ & Direct Intentional Management ${ }^{\dagger}$ & Indirect Intentional Management \\
\hline Ecosystem & $\begin{array}{l}\text { Modifying or actively protecting ecosystem structure, processes, } \\
\text { and functions that are relevant for the service, e.g., changing land } \\
\text { use or planting trees or crops. }\end{array}$ & $\begin{array}{l}\text { Creating enabling conditions, i.e., material, financial, knowledge, } \\
\text { and skills; restricting or controlling direct management; and } \\
\text { coordinating and supervising actors. }\end{array}$ \\
\hline Service & $\begin{array}{l}\text { Adding human inputs, e.g., work, knowledge, and tools, to } \\
\text { ecosystem functions to create, enhance, or complement ESs, e.g., } \\
\text { tools to improve crop growth and harvest crops, local knowledge } \\
\text { to allow collection of medicinal plants, and workforce to remove } \\
\text { garbage from a scenic road. }\end{array}$ & \\
\hline Use & $\begin{array}{l}\text { Allocating ESs or facilitating their flow for different purposes and } \\
\text { beneficiaries, e.g., transporting and marketing products, building } \\
\text { water infrastructure for treatment or distribution, controlling } \\
\text { settlements in flood-prone areas, and facilitating tourist access to } \\
\text { scenic places. }\end{array}$ & \\
\hline
\end{tabular}

e.g., prevention of negative impacts or maintenance costs, and tangible or intangible, e.g., spiritual satisfaction.

We define ES managers as the stakeholders who directly and indirectly influence ES flows along the cascade. Managers can simultaneously affect several services in an unexpected way because of synergies and trade-offs between ESs, i.e., positive and negative interactions between ESs (Hauck et al. 2013, Turner et al. 2013, Martinez-Harms et al. 2015, Vallet et al. 2018). Given the complexity and uncertainties of these interactions, we restricted our definition of ES management to any intentional actions that aimed to influence a specific ES, and we thus disregarded negative and positive externalities affecting ESs. The notion of intentionality is crucial for explaining environmental management, as several authors have observed (Lewin and Volberda 2003, Heugens 2006, Sánchez-Medina et al. 2014). For example, all stakeholders have unintentional influences on the global climate through the carbon emissions caused by their activities, but we did not consider all stakeholders to be ES managers because of the lack of intentionality.

Direct managers affect the functioning of ecosystems and the amount of services provided to or benefits received by society (Table 2). They correspond to the stakeholders involved in the coproduction of ESs. Indirect managers facilitate and restrict the activities of direct managers or control the benefits received by society. This distinction between beneficiaries and direct and indirect managers coincides with that made by Ostrom (1990) who distinguished three types of stakeholders in the management of natural resources: "appropriators," who use and withdraw natural resources; "producers," who implement actions to ensure the resource; and "providers," who arrange for the provision of natural resources. This distinction is also aligned with the typology of stakeholders proposed by Barnaud et al. (2018).

We considered that direct and indirect ES management can occur at the first three steps of the cascade, i.e., ecosystem, service, and use, but not at the last one, i.e., the benefits received from ES use (Fig. 1, Table 2). At the service level, most ecosystem functions do not require any human inputs to become regulating and cultural services, e.g., water infiltration resulting in pure water. However, some human inputs can improve them, e.g., a dam to improve the regularity of water availability. The concept of socialecological services proposed by Huntsinger and Oviedo (2014) might be more appropriate to highlight the importance of social systems, with their cultural, economic, and legal specificities, in the delivery of ESs in addition to the ecological systems and functions. However, for the sake of simplicity, we use the term ecosystem services (ESs) in what follows.

\section{STUDY SITE}

The Mariño River watershed $\left(319 \mathrm{~km}^{2}\right)$, centered on the coordinates $13^{\circ} 38^{\prime} \mathrm{S}$ and $72^{\circ} 53^{\prime} \mathrm{W}$ and located in the Apurimac region on the eastern slopes of the southern Peruvian Andes, ranges from 1613 to $5180 \mathrm{~m}$ above sea level (Fig. 2). This study site is located in one of the poorest regions of Peru: in 2013, among 24 regions in Peru, the Apurimac region ranked the third lowest in terms of Human Development Index and the second lowest in terms of incomes per capita (Programa de las Naciones Unidas para el Desarrollo 2013). Approximately 60,000 inhabitants are concentrated in 2 major urban areas, Abancay and Tamburco. Urban activities are mostly commercial and administrative (Instituto Nacional de Estadística e Informática [INEI] 2007). The main land uses are natural grasslands (37\% of the area), agricultural areas (37\%), and scrub or shrub lands $(13 \%$; Ministerio del Ambiente 2015).

Small-scale family farming is the predominant form of agriculture. Livestock farming often complements crop agriculture in the entire area, i.e., cattle breeding for meat and milk, and sheep, pigs, and small stock such as chickens and guinea pigs (Unidad Ejecutora Pro Desarrollo Apurímac 2010). At high elevations, common crops are corn and potatoes and, to a lesser extent, cereals, legumes, and Andean tubes and roots. Natural grasslands and bofedales, i.e., altitude wetlands, are extensively grazed. At midelevation, most agricultural land is terraced for green vegetables or seasonal fruit trees. Cattle graze on sown pastures and harvested fields. Agriculture at high and midelevations is subsistence oriented, i.e., surplus crops are sold at local markets, with traditional technologies, such as collective gravity irrigation systems, being used and giving low yields (INEI 2012). By contrast, livestock are often marketed and sold because they provide alternatives for savings and are a means of income 
Fig. 2. Map of the study site. Altitude ranges from $1613 \mathrm{~m}$ to $5180 \mathrm{~m}$ above sea level. The city of Abancay appears in red in the center of the map. The study site limits (brown line) correspond to the boundaries of the Mariño watershed.

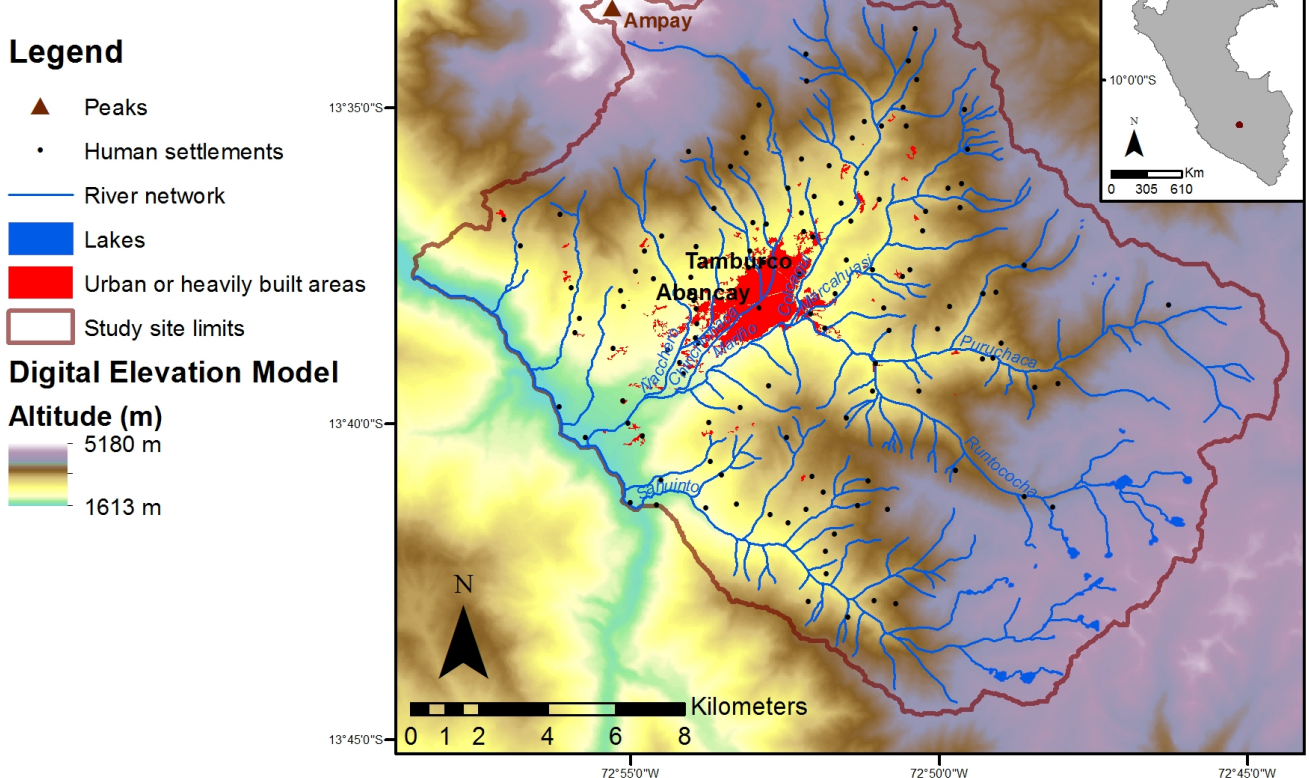

diversification (Unidad Ejecutora Pro Desarrollo Apurímac 2010). At low elevations, both crop and livestock farming are commercially oriented and generally more intensive. Crops include vegetables, fruits, fodder, and sugarcane, with mechanical equipment, agrochemical products, and modern irrigation systems, i.e., spray or drip irrigation, being used (Unidad Ejecutora Pro Desarrollo Apurímac 2010). Products are mainly sold in Abancay central markets, although some, e.g., avocado, cattle, and beans, are sold in distant markets.

Small agro-industrial businesses produce cheese, liquors, and jam or manage fish farms. Mining activities are limited to nonmetallic extraction, with the extraction of granular material for construction or clay for tiles and bricks. The Ampay Forest Sanctuary protects 3635 ha of land (Servicio Nacional de Áreas Naturales Protegidas por el Estado 2016), including the remaining Intimpa forest patches (Podocarpus glomeratus), an endangered native conifer species (International Union for Conservation of Nature 2011), and is the main tourist attraction in the area. Tourist spots, e.g., a colonial bridge, colonial churches, older estate manor houses, and thermal baths, receive a few visits, but tourism is still nascent in the area (Unidad Ejecutora Pro Desarrollo Apurímac 2010). Ecosystem changes are driven by uncontrolled urban growth and economic activities, unsustainable agricultural practices, and forest harvesting in addition to climate change (Gobierno Regional de Apurímac 2013). Several initiatives are being implemented to better protect ecosystems and their ESs, e. g., a retribution scheme for hydrological ESs and a subnational reforestation plan.

\section{METHODS}

Stakeholder analysis allowed us to identify stakeholders and analyze their behavior, concerns, roles, and interactions (BorriniFeyerabend et al. 2004, Reed et al. 2009). Such analysis has been used in other studies to understand stakeholders' roles and power in relation to ESs (Iniesta-Arandia et al. 2014, Felipe-Lucia et al. 2015). Our stakeholder analysis followed the three-step process proposed by Reed et al. (2009): identifying focus, i.e., ESs to study; identifying relevant stakeholders; and, finally, differentiating and categorizing stakeholders.

\section{Identifying focus}

In September 2015, we held a workshop with 21 representatives of diverse organizations that were directly implicated in natural resources management and development, i.e., public organizations, private companies, and NGOs, at the local and regional levels; we use "regional" to refer to the subnational administrative region. They were selected because of their sound knowledge of the area and its local environmental stakes. Following the methods used by Alonso Roldán et al. (2015), participants were provided with a list of $40 \mathrm{ESs}$, compiled from the Common International Classification of Ecosystem Services and Millennium Ecosystem Assessment (see Appendix 1; Millennium Ecosystem Assessment 2005, Haines-Young and Potschin 2013). After group discussions about the definition and importance of each ES, the participants were asked to place 10 stickers on the list to identify the ESs most at stake, i.e., beneficial and threatened. Participants could place more than 1 sticker on any of the ESs from the list. We then selected the ESs that received the most stickers and validated this short list with participants (see Appendix 1). Eight ESs were finally selected during this 
participatory process: agricultural production, medicinal plants, water quality, water quantity, mass erosion, sheet erosion, global climate regulation, and ecotourism. During this workshop, for each of the 8 selected ESs, participants were also asked to identify all the stakeholders, i.e., people and organizations, that conserve, produce, or degrade a particular ES or benefit from it.

\section{Identifying relevant stakeholders}

Using the stakeholder mapping produced during the first workshop as a starting point, we organized a second workshop in May 2016 with 27 participants to further explore stakeholder identification. The same participants were invited to both workshops; however, in practice, the participants slightly differed. Participants in the second workshop were divided into 3 groups corresponding to the different modalities of interaction with ESs, i.e., ES benefits, direct ES management, and indirect ES management, as defined in our framework. Each group was asked to list and describe the stakeholders experiencing these modalities for each of the $8 \mathrm{ESs}$ selected during the first workshop. Group results were then discussed collectively. To avoid omissions, the stakeholder list produced during this workshop was compared with those provided by local studies (Consorcio para el Desarrollo Sostenible de la Ecorregión Andina 2014, Solano Cornejo 2015). The final list included 52 stakeholders (Appendix 2). Strictly speaking, these are "stakeholder types," i.e., farmers, inhabitants, and so forth, and we did not consider the number of individuals per type. However, for the sake of simplicity, we use the word "stakeholders" in the following, except when the term may lead to confusion or misinterpretation.

We described the stakeholders according to their scale of intervention, i.e., local, subnational, national, and international, and their sectors. We categorized them into 4 sectors: public organizations, i.e., organizations managed by national, regional, and local governments, including governmental services and public enterprises $(n=27)$; businesses, i.e., companies run with the intention of making a profit $(n=10)$; NGOs, i.e., nonprofits and NGOs that address social or environmental issues $(n=8)$; and civil society, i.e., voluntary associations or groups of individuals, such as irrigation committees, farmers associations, or hiking clubs $(\mathrm{n}=7)$.

\section{Differentiating and categorizing stakeholders}

We conducted a total of 65 face-to-face semistructured interviews with representatives of the 52 identified stakeholders to understand how they managed and benefited from ESs (refer to the interview guide in Appendix 3). For stakeholders representing large or diverse groups of individuals or complex organizations, e.g., farmers and regional government, we conducted several interviews with different representatives and combined the collected information. We stopped when the interviews did not bring any additional information about stakeholders. For example, we interviewed 3 representatives of rural populations and 4 representatives of regional government offices in charge of economic development (see Appendix 2 for more details on the number of interviews conducted for each stakeholder). We started interviews by asking the representatives to describe their activities related to natural resources and development. We made it clear to the respondents that they were expected to represent the position of their institution and not their personal views. We then asked them to describe how they benefit from the 8 ESs and how they directly or indirectly manage them. Interviews were performed by the first author in June 2016; they each lasted between 45 and 90 minutes and were recorded if interviewees consented. We complemented the interviews with 4 months of field observations between May 2015 and December 2016. Field observation is a useful approach to better understand stakeholders' roles and activities in complex systems (Mason 2002, Berbés-Blázquez et al. 2017).

We transcribed and coded all the interviews. The coding categories were defined after the interviews to capture the diversity of management modalities mentioned by the interviewees for the eight selected ESs. The coded information was then compiled into a database, which recorded the benefits of each ES for each stakeholder and the different management activities applied by each stakeholder to each ES: step of the cascade, i.e., ecosystem, service, or use; management form, i.e., direct or indirect; management activity, i.e., act directly, coordinate and supervise, provide finance, provide knowledge and skills, provide supplies and materials, regulate ES flows, or restrict ES degradation; and detailed description.

To detect significant differences in ES benefits or management with regard to stakeholders' sectors and scales, we used permutation tests and mosaic plots to visualize the outcome of an independence test using the double maximum statistic of Pearson residuals. For this analysis, we applied three R packages: coin (Hothorn et al. 2006), rcompanion (Mangiafico 2018), and vcd (Meyer et al. 2017). We also manually clustered stakeholders depending on their influence over and interest in ESs following the previous studies of Iniesta-Arandia et al. (2014) and FelipeLucia et al. (2015) on the influence/dependence matrix. We used the mean numbers of managed and received ESs to separate the groups. Following Reed et al.'s (2009) study, stakeholders were classified as "key players," i.e., stakeholders with high benefits and high management involvement; "context setters," i.e., high involvement in ES management but few benefits; "subjects," i.e., high benefits but low involvement in ES management; and "crowd," i.e., few benefits and little involvement in ES management.

\section{RESULTS}

\section{Overview of ecosystem service benefits and management}

Workshops and interviews revealed the diversity of stakeholders and modalities of ES benefits and management. We report the results of the three ESs that received the most stickers in the participatory process, i.e., one per ES category: agricultural production (provisioning), water quantity (regulating), and ecotourism (cultural). See Appendix 4 for a description of the remaining ESs. For more detailed information on the stakeholders, refer to Appendix 2.

\section{Ecosystem service beneficiaries}

Water quantity benefited 14 stakeholder types, all at the local scale, including rural and urban populations, communities, and businesses that used water for their activities, e.g., fish farms, agroindustries, companies or organizations providing drinking and irrigation water, hotels, and restaurants. Agricultural production benefited 4 stakeholder types, also at the local scale: urban populations, for subsistence; rural populations, for subsistence and income generation; rural communities, for income from 
Table 3. Examples of management activities for three ecosystem services (ESs) at the study site.

\begin{tabular}{|c|c|c|}
\hline & Direct: Act Directly & $\begin{array}{l}\text { Indirect: Coordinate and Supervise (CS), Provide Finance (PF), Provide } \\
\text { Knowledge and Skills (PK), Provide Supplies and Materials (PS), Regulate } \\
\text { ES Flows (RF), and Restrict ES Degradation (RD) }\end{array}$ \\
\hline \multicolumn{3}{|c|}{ Agricultural production } \\
\hline Ecosystem level & $\begin{array}{l}\text { Rural population creates new agricultural } \\
\text { lands, sows crops, or plants trees. }\end{array}$ & $\begin{array}{l}\text { Agriculture Ministry services train farmers (PK). Municipalities control } \\
\text { activities that negatively affect croplands, e.g., urbanization (RD). }\end{array}$ \\
\hline Service level & $\begin{array}{l}\text { Farmers cultivate and harvest crops and raise } \\
\text { cattle. }\end{array}$ & $\begin{array}{l}\text { Regional government services in charge of agriculture train farmers (PK). } \\
\text { Nongovernmental organizations (NGOs) provide breeds of small stocks to } \\
\text { farmers (PS). Communities with customary laws on communal pastures } \\
\text { and the National Protected Area Service restrict grazing in some areas } \\
\text { (RF). }\end{array}$ \\
\hline Use level & $\begin{array}{l}\text { Rural population transports and markets } \\
\text { products. }\end{array}$ & $\begin{array}{l}\text { NGOs organize fairs and create labels (PK). National Agrarian Sanitary } \\
\text { Service controls product quality (RF). }\end{array}$ \\
\hline \multicolumn{3}{|r|}{$\mathrm{C}_{\mathrm{P}}$} \\
\hline Ecosystem level & $\begin{array}{l}\text { Rural populations or irrigation committees } \\
\text { reforest upper watershed. Communities } \\
\text { protect wetlands with fences. }\end{array}$ & $\begin{array}{l}\text { NGOs train rural populations and communities in wetland management } \\
\text { (PK). Municipalities define protected areas to protect water resources } \\
\text { (RD). }\end{array}$ \\
\hline Service level & $\begin{array}{l}\text { Communities build traditional small-scale } \\
\text { dams to improve water regulation. }\end{array}$ & $\begin{array}{l}\text { NGOs train communities and rural populations to construct dams (PK) } \\
\text { and provide materials for the construction of dams (PS). }\end{array}$ \\
\hline Use level & $\begin{array}{l}\text { Irrigation committees manage canals to } \\
\text { transport water. Regional government and } \\
\text { NGOs build water infrastructure for water } \\
\text { distribution. }\end{array}$ & $\begin{array}{l}\text { National Water Authority grants water licenses (RF). Companies or } \\
\text { associations charge fees for irrigation and drinking water (RF). } \\
\text { Environment Ministry supervises stakeholders using water (CS). }\end{array}$ \\
\hline \multicolumn{3}{|c|}{ Scenic beauty and recreation } \\
\hline Ecosystem level & Urban populations reforest city streets. & $\begin{array}{l}\text { Municipalities provide tree seedlings (PS). Municipalities and National } \\
\text { Protected Area Service control settlements in protected areas (RD). }\end{array}$ \\
\hline Service level & Tour operators or associations clean sites. & $\begin{array}{l}\text { National Protected Area Service controls activities that may degrade scenic } \\
\text { beauty, e.g., trash disposal (RF). }\end{array}$ \\
\hline Use level & $\begin{array}{l}\text { National Protected Area Service creates } \\
\text { hiking trails or installs trail signs. Tour } \\
\text { operators guide or host tourists. Taxis offer } \\
\text { transport services. }\end{array}$ & $\begin{array}{l}\text { A public organization funds studies to create new hiking trails (PF). NGOs } \\
\text { train rural populations to guide and host tourists (PK). Hotels and } \\
\text { restaurants distribute information about tourist attractions (PK). National } \\
\text { Protected Area Service restricts tourist activities and access to protected } \\
\text { areas through entrance fees and supervision (RF). }\end{array}$ \\
\hline
\end{tabular}

collective plantations; and agro-industries, for profit. Ecotourism benefited 2 stakeholder types at the national scale, i.e., tourists and the National Protected Area Service for the incomes generated by entrance fees, and 6 stakeholder types at the local scale: local hiking or bicycle clubs and businesses and individuals providing services to tourists, i.e., nature guides, tourism and transportation companies, hotels, restaurants, and communities or individuals providing housing and food services.

\section{Ecosystem service managers}

For water quantity, direct management, i.e., activities affecting the functioning of ecosystems and the number of services provided to society or benefits received, related to the modification of the land cover or soil properties or the construction and operation of infrastructure for drinking and irrigation water (see Table 3 for examples). Indirect management, i.e., activities that facilitate or restrict the activities of direct managers or control the benefits received by society, consisted, for example, of providing technical support to farmers for land management and controlling or restricting ES flows through irrigation and drinking water prices.

For agricultural production, direct activities consisted, for example, of planting crops, cultivating fields, raising animals such as cattle and fish, improving irrigation systems, and transporting and selling food production on the markets. Indirect management included the restriction of agricultural activities in the natural protected area; the control of agrochemicals used; financial or material support, such as equipment, seeds, and animals; marketing support, in particular through product certification; and technical assistance for the control of diseases and plagues, the improvement of food production, or the conversion to agroecological production.

For ecotourism, direct management consisted of reforesting urban areas, cleaning tourist spots, improving tourist offerings such as opening new hiking trails, and transporting and guiding tourists. Indirect management included the restriction and punishment of vandalism in tourist spots; the control of the activities affecting landscape aesthetics, such as urbanization, mining, and so forth; training of local guides, rural guesthouses, hotels, and restaurants; the control and regulation of visitor entrance to the natural protected area; and the dissemination of tourist information.

Indirect management activities were further organized into six categories defined after the interviews and using the information on the eight ESs: coordinate and supervise (CS), provide finance $(\mathrm{PF})$, provide knowledge and skills (PK), provide supplies and materials (PS), regulate ES flows (RF), and restrict ES degradation (RD; Table 3). These categories were useful to describe and explore the diversity of indirect management activities implemented by the stakeholders in the study site, using a relatively simple typology to disentangle the complexity of 
Fig. 3. Diversity of stakeholders, i.e., number of different stakeholder types, at each step of the cascade and for the two different modalities of management: direct and indirect. Different options of indirect management are distinguished: coordinate and supervise actors (CS), provide finance (PF), provide knowledge and skills (PK), provide supplies and materials (PS), regulate ecosystem service flows (RF), and restrict ecosystem service degradation (RD).

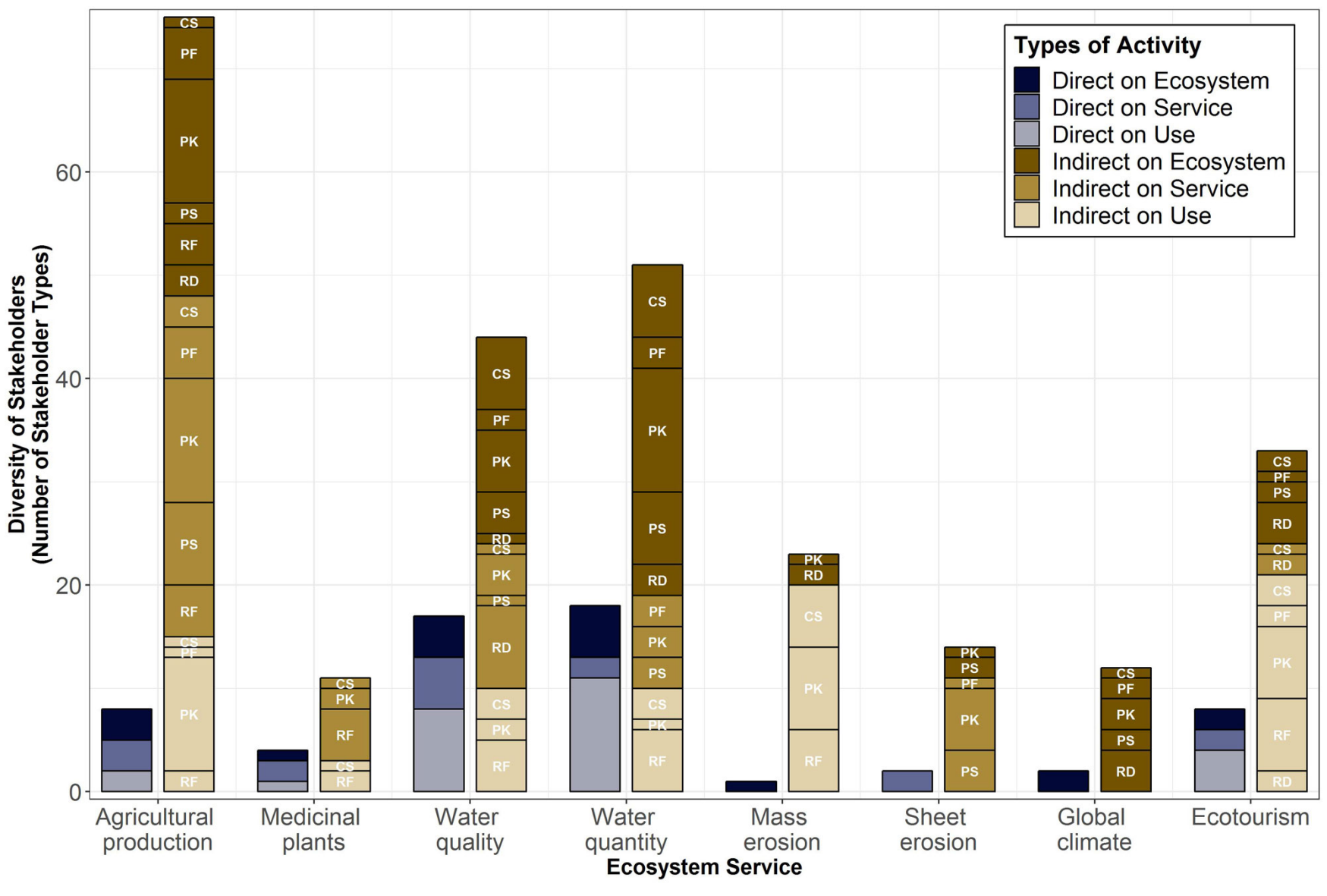

management strategies. Across the eight ESs studied, indirect forms of ES management were more frequent than direct ones for all ESs (Fig. 3). There were more management activities undertaken by more stakeholder types at the level of ecosystems, both directly and indirectly, than at other levels. Water-related ESs were managed by the highest number of stakeholder types for direct management and were second after food production for indirect management. Although some ESs, e.g., water quality, water quantity, and medicinal plants, were managed at the three steps of the ES flow cascade, other ESs such as sheet erosion and global climate regulation were only managed at one level, i.e., service and ecosystem, respectively. Indirect management focused on the ecosystem level in the case of water and on the use level in the case of mass erosion and ecotourism, e.g., impeding activities in landslide-prone areas or facilitating visitor access.

Who benefits from ecosystem services?

ESs were significantly more likely to benefit stakeholders from business and civil society than those from NGOs and the public sector. Beneficiaries were significantly more likely to act at the local scale than at higher levels (see the association plots in Appendix 5, Fig. A5.1). Stakeholders benefited from different numbers of ESs ranging from 0 to 7, i.e., none benefited from all selected ESs, with civil society, businesses, and local stakeholders significantly benefiting from more ESs compared with other stakeholders (Fig. 4).

Who manages ecosystem services?

Stakeholders from different sectors managed ESs differently: the public sector and national stakeholders were significantly less involved in direct management and more involved in indirect management, whereas businesses, civil society, and local stakeholders were significantly more involved in direct management and less in indirect management (see association plots in Appendix 5, Fig. A5.2). Stakeholders managed different numbers of ESs ranging from 0 to 8, i.e., some managed all selected ESs, with NGOs and the public sector managing more ESs than the business sector. No differences in the number of managed ESs were found between scales (Fig. 4). 
Ecosystem services managed by many stakeholder types do not necessarily benefit many stakeholder types

The selected ESs benefited and were managed by different numbers of stakeholder types. Mass erosion and global climate regulation were managed by few stakeholder types but benefited many stakeholder types, whereas the opposite was true for agricultural production. Water services had the highest diversity of both managers and beneficiaries (Fig. 5).

Fig. 4. Number of received and managed ecosystem services (ESs) according to sector (A) and scale (B). BUS, business; LOC, local; NAT, national and international; NGO, nongovernmental organizations; PUB, public sector; SOC, civil society; SUB, subnational. Lowercase and uppercase letters indicate significant differences in the number of received ESs and managed ESs, respectively (pairwise permutation tests, with alpha $=0.05)$.

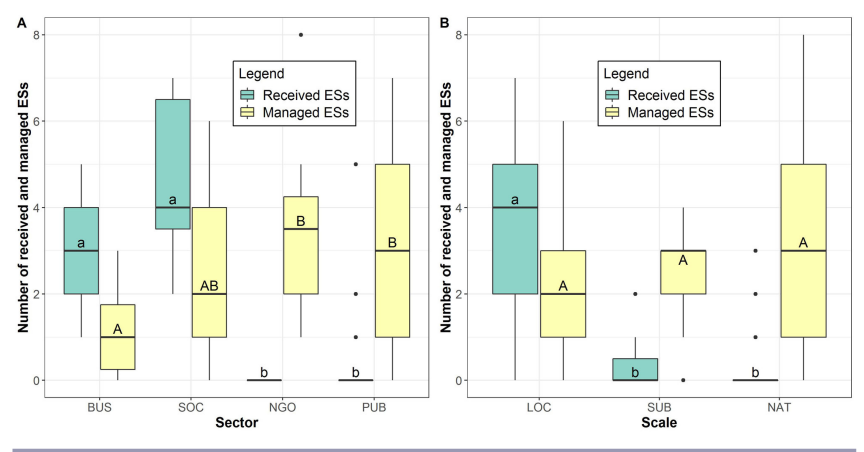

Stakeholders benefiting from ecosystem services do not necessarily participate in ecosystem service management Stakeholders differed considerably in terms of how they managed and benefited from ESs. Direct managers were significantly more likely to be beneficiaries (see association plots in Appendix 5, Fig. A5.3). Stakeholders with direct management activities on ESs significantly benefited from more ESs than stakeholders with indirect activities (Fig. 6A). Four groups of stakeholders could be identified using a manual classification based on the number of ESs that they managed or benefited from (Fig. 6B). Stakeholders from the "subjects" group were likely to be from businesses and act at the local scale; stakeholders from the "key players" group were likely to be from civil society and act at the local scale; and stakeholders from the "context setters" group were unlikely to act at the local scale (see association plots in Appendix 5, Fig. A5.4). Only six stakeholders were found in the "key players" group (Appendix 6): rural communities, rural populations, the National Protected Area Service, transport companies, fish farmers, and irrigation committees.

\section{DISCUSSION}

\section{Diversity of stakeholders involved in ecosystem service management}

Water quantity, water quality, and agricultural production were managed by the largest number of stakeholder types. Our findings agree with those of Alonso Roldán et al. (2015) who observed that more actors were involved in the management and governance of water-related ESs in arid ecosystems where water is scarce. In our study site, water-related services showed high numbers of beneficiaries and stakeholder types involved in their management, which underlines their strong importance in the area. Similar to the findings of Alonso Roldán et al. (2015), we observed a mismatch between the number of stakeholder types benefiting from one ES and the number of stakeholder types involved in its management, with some ESs being managed by many stakeholder types but showing few beneficiaries, e.g., food production, and vice versa, e.g., mass erosion.

Fig. 5. Number of stakeholder types benefiting from and managing each ecosystem service (ES).

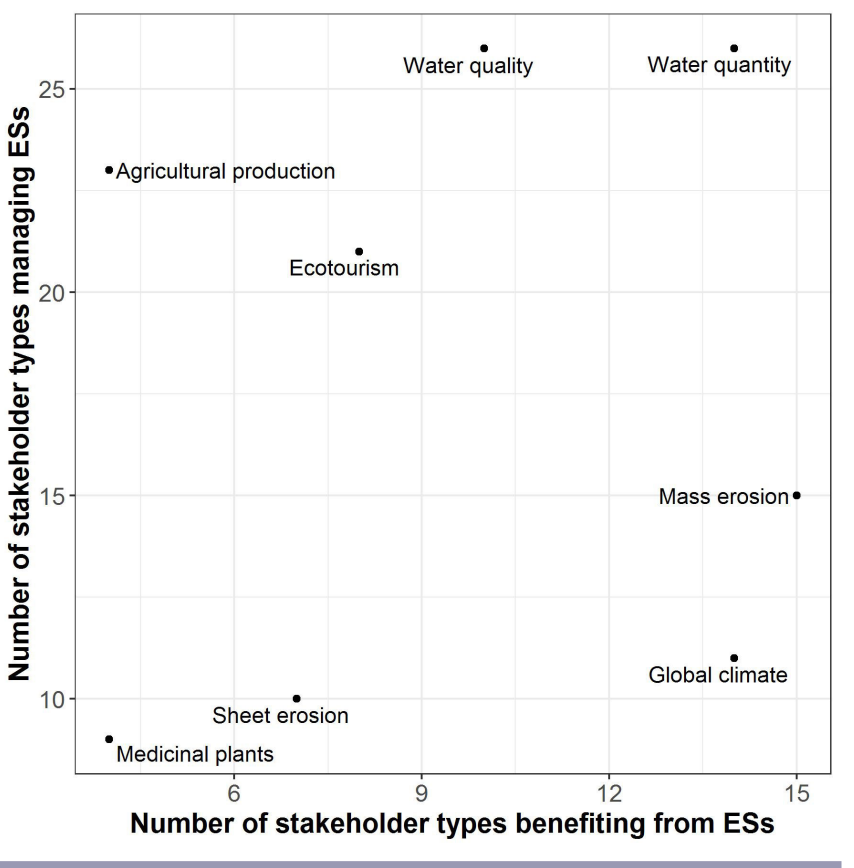

The high variability of stakeholder types involved in the management of different ESs can be explained by different rationales and intentional choices such as the preference for local benefits over national or global ones. For example, in the Mariño watershed, the management of water-related ESs involved more diverse stakeholders than global climate regulation through carbon sequestration. It has been observed elsewhere that local decision making on climate change generally favors local adaptation benefits, e.g., improved water management, over mitigation benefits that are delivered globally, unless incentives are used to reward carbon sequestration (Locatelli et al. 2015).

Some of our findings could be explained by the fact that the stakeholder types considered in the analysis do not necessarily take into account the size of the population that they represent. For example, rural populations for which agricultural production is crucial in terms of subsistence and income were considered in the analysis as a single stakeholder, even though they represent more than 7000 people. Moreover, institutions are supposed to represent the interests of different stakeholder groups. This underlines the difficulty of comparing organizations and individuals in such an analysis. The number of stakeholders might thus be as important as the diversity of stakeholders involved in ES benefits or management. 
Fig. 6. Differences in ecosystem service (ES) management and benefits. (A) Number of ESs benefiting stakeholders implementing direct and indirect management. Letters indicate significant differences (pairwise permutation tests, with alpha $=0.05$ ). $(\mathrm{B})$ Number of benefiting and managed ESs for each stakeholder. Jitter was added to improve the visualization of the two discrete variables and avoid overlap of points (factor $=2$ ). Lines indicate mean values on both axes. BUS, business; LOC, local; NAT, national and international; NGO, nongovernmental organizations; PUB, public sector; SOC, civil society; SUB, subnational.
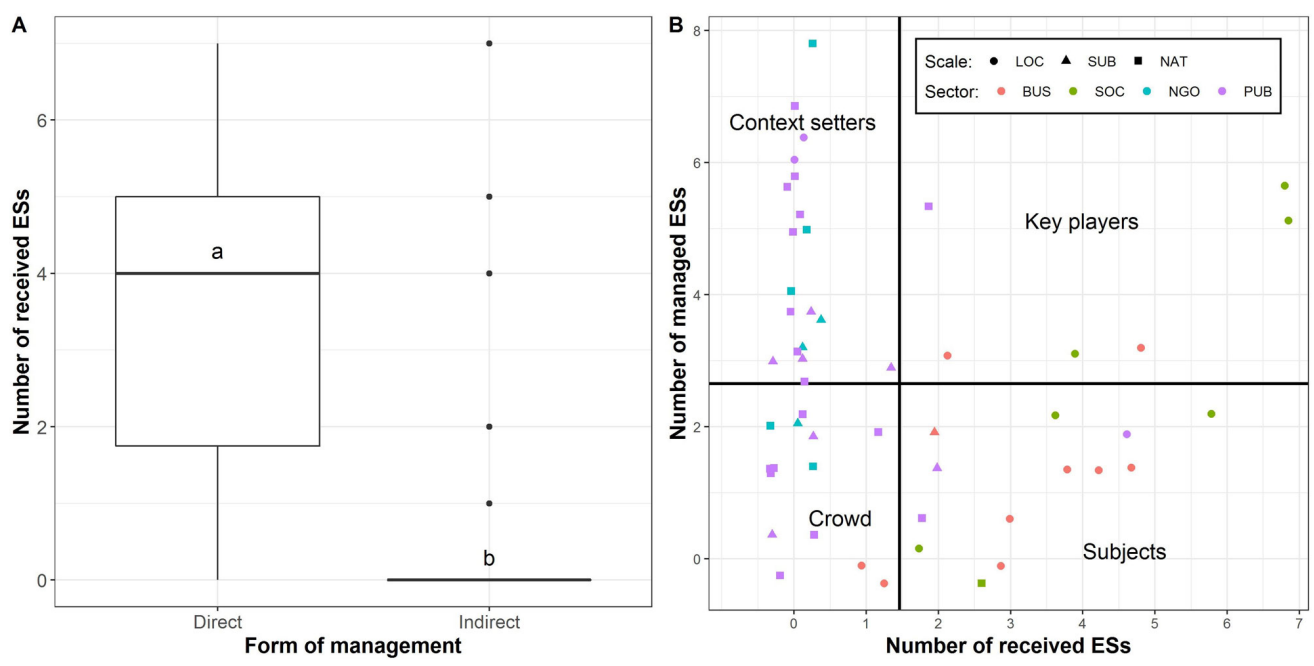

Benefiting from and managing the ecosystem service cascade We proposed a framework to describe stakeholders' influence on the ES cascade and link it to the benefits received. Regarding the Mariño watershed, we used the number of received ESs as a proxy for interest and the number of managed ESs as a proxy for influence. Other ways of applying the interest and influence matrix proposed by Reed et al. (2009) have been suggested in the literature. For example, some authors focus on dependence on ESs instead of ES benefits (Iniesta-Arandia et al. 2014, FelipeLucia et al. 2015). However, quantifying the dependence levels of different stakeholders may be challenging. For example, rural populations are highly dependent on food production to meet their basic needs, but so too are agribusinesses, as they depend on agricultural products for their economic activities. Focusing on ES benefits rather than dependence on ESs may thus be a more neutral and less value-loaded approach to characterize the interactions between humans and nature.

The benefit side of our framework could be refined to better describe how ESs can benefit human well-being. First, it would be interesting to further detail the type of benefits received by distinguishing between direct benefits, i.e., income or goods, and indirect benefits, i.e., avoided costs or general negative impacts, or between tangible benefits, i.e., the material dimension, and intangible benefits, i.e., the spiritual dimension (e.g., Suwarno et al. 2016). Second, because some stakeholders benefit greatly from one ES but minimally from another, future improvements could also focus on the intensity of benefits received by stakeholders. Finally, the contributions of ESs to different dimensions of wellbeing could be disentangled and added to the framework (Fisher et al. 2014).

Regarding the proxy used for influence, i.e., number of managed ESs, this is somewhat questionable, as one stakeholder might be extremely influential but manage only one important ES. Our description of stakeholders' influence would indisputably gain from a more complex approach that takes into account the nature of the management activity, the number of affected stakeholders, and the relationships among stakeholders during ES management. Despite its simplification, our approach offers a straightforward and easily replicable means to quantitatively assess stakeholders' influence on the ES cascade.

\section{Influencing the ecosystem service cascade: a question of power} In our framework, the stakeholders involved in the first steps of the ES cascade, i.e., ecosystem level, control the benefits received in the last step, i.e., benefit level. ES flows create structural interdependencies and power relationships among stakeholders (Felipe-Lucia et al. 2015, Barnaud et al. 2018, Turkelboom et al. 2018). For example, farmers who manage agricultural production by planting crops, i.e., ecosystem level, and cultivating them, i.e., service level, influence the quantity of food available to consumers. To some extent, an analogy might be observed with the power distribution in organizations. As Brass (1984:522) observed: "When a task position is critical to the continued flow of work, the position holder may be potentially powerful."

Power is exerted by different stakeholders at different levels of the cascade. For example, our results showed that farmers and communities were powerful in influencing land management and water supply, but powerless in deciding the allocation of water use among various users. On the contrary, the National Water Authority was powerless in terms of land management, but powerful in controlling and authorizing water consumption. To better understand the various influences over the ES cascade, we need to analyze how power over the ES flow is used, i.e., to which purpose and in which decision-making arenas, and how stakeholders can effectively contribute to ES governance. 


\section{Distribution of stakeholders' roles in relation to the ecosystem service cascade}

We found clear differences in the identity of stakeholders who managed or benefited from ESs, as shown in other studies conducted in different contexts (Ernstson et al. 2008, Alonso Roldán et al. 2015, Felipe-Lucia et al. 2015). First, we found that ES benefits were predominantly received by certain stakeholders, e.g., local stakeholders and businesses. Other studies observed similar patterns in Indonesia and Nepal, for example (Suwarno et al. 2016, Chaudhary et al. 2018). Second, we also found that public organizations and NGOs were most involved in ES management, mainly indirectly, as also observed elsewhere (Alonso Roldán et al. 2015, Felipe-Lucia et al. 2015, Turkelboom et al. 2018). This calls for more place-based research to better characterize the general patterns of identity regarding stakeholders' roles (Balvanera et al. 2017).

We found many stakeholders in the categories of "subjects," i.e., benefiting from many ESs but managing few of them, and "context setters," i.e., benefiting from few ESs but managing many of them. We found a limited number of stakeholders in the "key players" category, corresponding to stakeholders who benefit from and manage many ESs. This would suggest that the power of influencing and managing the ES cascade is poorly shared with ES beneficiaries in the Mariño watershed. This power asymmetry raises several concerns, as observed in other studies (Ernstson et al. 2008, Felipe-Lucia et al. 2015), because it may cause the population's mistrust of institutions (legitimacy concern), create conflicts, or reduce the resilience and adaptive capacity of a socialecological system (Olsson et al. 2004, Armitage et al. 2009).

\section{Participatory management of ecosystem services for equitable governance?}

More equitable governance of ESs could aim to integrate more diverse stakeholders into decision making, for example, by empowering stakeholders from the "subjects" category to become "key players" (Olsson et al. 2004, Turkelboom et al. 2018). Stakeholders can jointly manage natural resources under multiple modalities such as information sharing, consultation, participation in advisory committees or management boards, and community control or partnerships (Borrini-Feyerabend et al. 2004). In the Mariño watershed, participatory platforms already exist, i.e., local and regional environmental commissions. However, the private sector, rural and urban populations, and civil society currently have limited direct participation. They are rather indirectly represented through NGOs. Their direct participation in these arenas could be a way for them to gain more influence. For example, the retribution scheme for hydrological ESs proposed in the watershed also offers opportunities for collective action and coordination between diverse stakeholders, i.e., communities, rural populations, public organizations, and NGOs.

Finally, it is worth noting that in some cases, the inequitable distribution of stakeholders' roles might not be a problem per se, because some ES beneficiaries have no interest in participating in management. For example, in our study case, remote beneficiaries such as international tourists benefiting from ecotourism in the Mariño watershed have limited interest in local ES management.

\section{Mechanisms underpinning power asymmetries}

Our study highlights the existence of power asymmetries in relation to ES management and benefits in the Mariño watershed, but it does not provide a clear understanding of the mechanisms responsible for the observed inequities. Our framework includes two mechanisms that may conceptually explain equity and power asymmetry: first, it recognizes that stakeholders have different rights and entitlements, and second, it considers social and spatial interactions among stakeholders. Other studies have underlined the importance of rules, institutions, and individual stakeholder characteristics, which mediate access to and control of ESs (Fisher et al. 2014, Berbés-Blázquezet al. 2017). Further empirical research could use our framework to explore the factors determining stakeholders' roles and power distribution. There is a particular need to understand how rights, endowments, and entitlements underpin inequities in different social and cultural contexts (Sen 1984, Ostrom 1990, Leach et al. 1999).

In the Mariño watershed, the information we collected might suggest that different entitlements and rights are responsible for the differentiated roles in relation to the ES cascade. For example, residents who have lived and cultivated land inside the protected area before its creation can continue as before, whereas other stakeholders are prohibited from starting new farming activities. In this example, the difference stems from the formal rights defined by law. However, differences can also be explained by unequal forms of individual capital, i.e., endowments in Sen's theory. For example, plant gatherers drive or walk to the highlands to collect medicinal plants, depending on their physical capital, and have different knowledge about the curative effects of the plants, i.e., human capital, which determines their income. Stakeholders' capabilities, as well as different forms of capital, i.e., financial, natural, produced, human, and social, form the basis of stakeholders' power for controlling and using natural resources (Giddens 1979, Bebbington 1999, Goodwin 2003, Jenkins 2009).

Our work also suggests that spatial dimensions are important. Space is a physical constraint that can prevent stakeholders from benefiting from or managing ESs. For example, only stakeholders living downstream from a forest will benefit from its water regulation capacity, and not those who live upstream. Spatial constraints can also result from social rules, institutions, and stakeholders' entitlements. For example, only the residents of a community can collect the medicinal plants that grow on community lands because of customary laws. Similarly, irrigation committees can only manage water in a given place, usually determined by water source or communities, but not in upstream or downstream areas managed by other irrigation committees. ES beneficiaries might be spatially disconnected from managers as in the case of water-related services (Wolff et al. 2015).

\section{Accounting for the multiple facets of power in ecosystem service governance}

We analyzed stakeholders' influence and power over the ES cascade, i.e., power exerted over an object. However, other forms of power can be exerted by stakeholders to influence ES governance, such as relational power, i.e., the power that people exert over each other regarding the management and governance of ESs (Barnaud et al. 2010). Forms of relational power are diverse and can include reward power, coercive power, legitimate power, referent power, and expert power (French and Raven 1959). These 
relational forms of power were overlooked in our study, which instead focused on the power to influence the ES cascade. However, as they are consistent and compatible with our framework, further research could integrate power relationships among ES managers and beneficiaries. Future research efforts could focus on the societal component of our framework to understand how relational power asymmetries are shaped by stakeholders' perceptions and values (Iniesta-Arandia et al. 2014), access to resources and information (Turkelboom et al.2018), and formal or informal relationships among stakeholders (BerbésBlázquez et al. 2016). For example, our framework could be articulated with either qualitative or quantitative approaches from social sciences, such as network analysis, to discuss different forms of relational power distribution through a structural perspective (Cook et al. 1983, Brass and Burkhardt 1993).

Moreover, we suggest that stakeholders handle different forms of power. For example, in the Mariño watershed, farmers can strongly influence agricultural production and water-related services, but they have limited capacities to propose, discuss, or oppose landscape management strategies with other stakeholders. There is therefore a need to identify and describe the different power strategies that stakeholders may devise to influence ES governance. It is also crucial to better understand how power asymmetries can affect ES governance and sustainability (Jacobs et al. 2016, Schröter et al. 2017, Barnaud et al. 2018). This calls for more empirical research linking ES science with environmental justice.

\section{CONCLUSION}

Our objective was to propose an analytical framework for identifying and qualifying stakeholders' roles based on the ES benefits received and their participation in ES management using an example in Peru. Water quantity, water quality, and agricultural production were managed by the largest number of stakeholder types. Local stakeholders and the business sector benefited from a higher number of ESs, and public organizations and NGOs were the most involved in ES management. We found clear differences in the identity of stakeholders who managed or benefited from ESs. Only a few stakeholders were found to be able to equally benefit from and influence the ES cascade, which could be explained by different rationales and intentional choices. Our framework and its application to the Mariño watershed offer interesting insights and provide a basis for discussing the issues of power distribution and equity. Stakeholders involved in the first steps of the ES cascade control the benefits received by society in the last one, which creates structural interdependencies and power relationships among stakeholders. Participatory management could be a way to empower less influential stakeholders. Future improvements of the framework could focus on the mechanisms underpinning the observed inequities and power asymmetries, as well as on other forms of relational power exerted in ES governance. More research linking political ecology, sustainability science, and ES research is needed to understand the issues of power and equity in ES governance.

\section{Responses to this article can be read online at:} http://www.ecologyandsociety.org/issues/responses. php/10904

\section{Acknowledgments:}

The funding partners that have supported this research include the International Climate Initiative (IKI) of the German Federal Ministry for the Environment, Nature Conservation, Building and Nuclear Safety (BMUB), the Norwegian Agency for Development Cooperation, the French Ministry of the Environment, Energy and Marine Affairs, and the CGIAR Research Program on Forests, Trees and Agroforestry (CRP-FTA) with financial support from the CGIAR Fund. The authors are grateful to Helvetas, Bosques Andinos, CEDES, and IDMA for logistical support and help organizing the workshops and interviews. The authors thank all interviewees for their time and useful information, Antoine Missemer for helpful discussions, and Camille Vallet for English editing.

\section{LITERATURE CITED}

Adger, W. N., K. Brown, and E. Tompkins. 2005. The political economy of cross-scale networks in resource co-management. Ecology and Society 10(2):9. https://doi.org/10.5751/ES-01465-100209

Alonso Roldán, V., S. Villasante, and L. Outeiro. 2015. Linking marine and terrestrial ecosystem services through governance social networks analysis in Central Patagonia (Argentina). Ecosystem Services 16:390-402. https://doi.org/10.1016/j. ecoser.2015.02.010

Armitage, D. R., R. Plummer, F. Berkes, R. I. Arthur, A. T. Charles, I. J. Davidson-Hunt, A. P. Diduck, N. C. Doubleday, D. S. Johnson, M. Marschke, P. McConney, E. W. Pinkerton, and E. K. Wollenberg. 2009. Adaptive co-management for socialecological complexity. Frontiers in Ecology and the Environment 7(2):95-102. https://doi.org/10.1890/070089

Ashley, C., D. Carney, and Department for International Development (DFID). 1999. Sustainable livelihoods guidance sheets. DFID, London, UK.

Balvanera, P., R. Calderón-Contreras, A. J. Castro, M. R. FelipeLucia, I. R. Geijzendorffer, S. Jacobs, B. Martín-López, U. Arbieu, C. I. Speranza, B. Locatelli, N. P. Harguindeguy, I. R. Mercado, M. J. Spierenburg, A. Vallet, L. Lynes, and L. Gillson. 2017. Interconnected place-based social-ecological research can inform global sustainability. Current Opinion in Environmental Sustainability 29:1-7. https://doi.org/10.1016/j.cosust.2017.09.005

Barnaud, C., E. Corbera, R. Muradian, N. Salliou, C. Sirami, A. Vialatte, J.-P. Choisis, N. Dendoncker, R. Mathevet, C. Moreau, V. Reyes-García, M. Boada, M. Deconchat, C. Cibien, S. Garnier, R. Maneja, and M. Antona. 2018. Ecosystem services, social interdependencies, and collective action: a conceptual framework. Ecology and Society 23(1):15. https://doi. org/10.5751/ES-09848-230115

Barnaud, C., A. van Paassen, G. Trébuil, T. Promburom, and F. Bousquet. 2010. Dealing with power games in a companion modelling process: lessons from community water management in Thailand highlands. Journal of Agricultural Education and Extension 16(1):55-74. https://doi.org/10.1080/13892240903533152

Bebbington, A. 1999. Capitals and capabilities: a framework for analyzing peasant viability, rural livelihoods and poverty. World 
Development 27(12):2021-2044. https://doi.org/10.1016/S0305-750X (99)00104-7

Berbés-Blázquez, M., M. J. Bunch, P. R. Mulvihill, G. D. Peterson, and B. van Wendel de Joode. 2017. Understanding how access shapes the transformation of ecosystem services to human wellbeing with an example from Costa Rica. Ecosystem Services 28C:320-327. https://doi.org/10.1016/j.ecoser.2017.09.010

Berbés-Blázquez, M., J. A. González, and U. Pascual. 2016. Towards an ecosystem services approach that addresses social power relations. Current Opinion in Environmental Sustainability 19:134-143. https://doi.org/10.1016/j.cosust.2016.02.003

Borrini-Feyerabend, G., M. Pimbert, M. T. Farvar, A. Kothari, and Y. Renard. 2004. Sharing power: learning-by-doing in comanagement of natural resources throughout the world. International Institute for Environment and Development, London, UK.

Brass, D. J. 1984. Being in the right place: a structural analysis of individual influence in an organization. Administrative Science Quarterly 29(4):518-539. https://doi.org/10.2307/2392937

Brass, D. J., and M. E. Burkhardt. 1993. Potential power and power use: an investigation of structure and behavior. Academy of Management Journal 36(3):441-470. https://doi.org/10.5465/256588

Chaudhary, S., A. McGregor, D. Houston, and N. Chettri. 2018. Environmental justice and ecosystem services: a disaggregated analysis of community access to forest benefits in Nepal. Ecosystem Services 29A:99-115. https://doi.org/10.1016/j. ecoser.2017.10.020

Consorcio para el Desarrollo Sostenible de la Ecorregión Andina (CONDESAN). 2014. Informe del DHR en la microcuenca del río Mariño. Ministerio del Ambiente, Magdalena del Mar, Peru.

Cook, K. S., R. M. Emerson, M. R. Gillmore, and T. Yamagishi. 1983. The distribution of power in exchange networks: theory and experimental results. American Journal of Sociology 89 (2):275-305. https://doi.org/10.1086/227866

Cutter, S. L. 1995. Race, class and environmental justice. Progress in Human Geography 19(1):111-122. https://doi.org/10.1177/030$\underline{913259501900111}$

Ernstson, H. 2013. The social production of ecosystem services: a framework for studying environmental justice and ecological complexity in urbanized landscapes. Landscape and Urban Planning 109(1):7-17. https://doi.org/10.1016/j.landurbplan.2012.10.005

Ernstson, H., S. Sörlin, and T. Elmqvist. 2008. Social movements and ecosystem services - the role of social network structure in protecting and managing urban green areas in Stockholm. Ecology and Society 13(2):39. https://doi.org/10.5751/ES-02589-130239

Fedele, G., B. Locatelli, and H. Djoudi. 2017. Mechanisms mediating the contribution of ecosystem services to human wellbeing and resilience. Ecosystem Services 28A:43-54. https://doi. org/10.1016/j.ecoser.2017.09.011

Felipe-Lucia, M. R., B. Martín-López, S. Lavorel, L. BerraqueroDíaz, J. Escalera-Reyes, and F. A. Comín. 2015. Ecosystem services flows: why stakeholders' power relationships matter. PLoS ONE 10(7):e0132232. https://doi.org/10.1371/journal. pone. 0132232
Fisher, J. A., G. Patenaude, K. Giri, K. Lewis, P. Meir, P. Pinho, M. D. A. Rounsevell, and M. Williams. 2014. Understanding the relationships between ecosystem services and poverty alleviation: a conceptual framework. Ecosystem Services 7:34-45. https://doi. org/10.1016/j.ecoser.2013.08.002

Folke, C., T. Hahn, P. Olsson, and J. Norberg. 2005. Adaptive governance of social-ecological systems. Annual Review of Environment and Resources 30:441-473. https://doi.org/10.1146/ annurev.energy.30.050504.144511

Freeman, R. E. 1984. Strategic management: a stakeholder approach. Pitman, Boston, Massachusetts, USA.

French, J. R., and B. Raven. 1959. The bases of social power. Pages 150-167 in D. Cartwright, editor. Studies in social power. Institute for Social Research, University of Michigan, Ann Arbor, Michigan, USA.

Giddens, A. 1979. Agency, structure. Pages 49-95 in Central problems in social theory: action, structure and contradiction in social analysis. Palgrave, London, UK. https://doi.

org/10.1007/978-1-349-16161-4 3

Gobierno Regional de Apurímac. 2013. Agenda agraria regional Apurimac. Dirección Regional Agraria de Apurímac, Abancay, Peru.

Göhler, G. 2009. 'Power to' and 'Power over.' Pages 27-39 in S. R. Clegg and M. Haugaard, editors. The SAGE handbook of power. SAGE, Thousand Oaks, California, USA. https://doi. org/10.4135/9780857021014.n1

Goodwin, N. R. 2003. Five kinds of capital: useful concepts for sustainable development. Global Development and Environment Institute Series, No. 03-07. Tufts University, Medford, Massachusetts, USA.

Haines-Young, R., and M. Potschin. 2010. The links between biodiversity, ecosystem services and human well-being. Pages 110-139 in D. G. Raffaelli and C. L. J. Frid, editors. Ecosystem ecology: anew synthesis. Cambridge University Press, Cambridge, UK. https://doi.org/10.1017/CBO9780511750458.007

Haines-Young, R., and M. Potschin. 2013. Common International Classification of Ecosystem Services (CICES): consultation on Version 4, August-December 2012. European Environment Agency, Copenhagen, Denmark.

Hauck, J., C. Görg, R. Varjopuro, O. Ratamäki, and K. Jax. 2013. Benefits and limitations of the ecosystem services concept in environmental policy and decision making: some stakeholder perspectives. Environmental Science \& Policy 25:13-21. https://doi. org/10.1016/j.envsci.2012.08.001

Heugens, P. P. M. A. R. 2006. Environmental issue management: towards a multi-level theory of environmental management competence. Business Strategy and the Environment 15 (6):363-376. https://doi.org/10.1002/bse.438

Horcea-Milcu, A.-I., J. Leventon, J. Hanspach, and J. Fischer. 2016. Disaggregated contributions of ecosystem services to human well-being: a case study from Eastern Europe. Regional Environmental Change 16(6):1779-1791. https://doi.org/10.1007/ s10113-016-0926-2 
Hothorn, T., K. Hornik, M. A. van de Wiel, and A. Zeileis. 2006. A Lego system for conditional inference. American Statistician 60(3):257-263. https://doi.org/10.1198/000313006X118430

Howe, C., H. Suich, B. Vira, and G. M. Mace. 2014. Creating winwins from trade-offs? Ecosystem services for human well-being: a meta-analysis of ecosystem service trade-offs and synergies in the real world. Global Environmental Change 28:263-275. https:// doi.org/10.1016/j.gloenvcha.2014.07.005

Huntsinger, L., and J. L. Oviedo. 2014. Ecosystem services are social-ecological services in a traditional pastoral system: the case of California's Mediterranean rangelands. Ecology and Society 19(1):8. https://doi.org/10.5751/ES-06143-190108

Iniesta-Arandia, I., M. García-Llorente, P. A. Aguilera, C. Montes, and B. Martín-López. 2014. Socio-cultural valuation of ecosystem services: uncovering the links between values, drivers of change, and human well-being. Ecological Economics 108:36-48. https://doi.org/10.1016/j.ecolecon.2014.09.028

Instituto Nacional de Estadística e Informática (INEI). 2007. Censos Nacionales 2007 : XI de Población y VI de Vivienda. INEI, Lima, Peru.

Instituto Nacional de Estadística e Informática (INEI). 2012. IV Censo nacional agropecuario. INEI, Lima, Peru.

International Union for Conservation of Nature (IUCN). 2011. Podocarpus glomeratus: Gardner, M.: The IUCN Red List of Threatened Species 2013: e.T42504A2983439. IUCN, Gland, Switzerland.

Ishihara, H., U. Pascual, and I. Hodge. 2017. Dancing with storks: the role of power relations in payments for ecosystem services. Ecological Economics 139:45-54. https://doi.org/10.1016/j. ecolecon.2017.04.007

Jacobs, S., N. Dendoncker, B. Martín-López, D. N. Barton, E. Gomez-Baggethun, F. Boeraeve, F. L. McGrath, K. Vierikko, D. Geneletti, K. J. Sevecke, N. Pipart, E. Primmer, P. Mederly, S. Schmidt, A. Aragão, H. Baral, R. H. Bark, T. Briceno, D. Brogna, P. Cabral, R. De Vreese, C. Liquete, H. Mueller, K. S.-H. Peh, A. Phelan, A. R. Rincón, S. H. Rogers, F. Turkelboom, W. Van Reeth, B. T. van Zanten, H. K. Wam, and C.-L. Washbourne. 2016. A new valuation school: integrating diverse values of nature in resource and land use decisions. Ecosystem Services 22B:213-220. https://doi.org/10.1016/j.ecoser.2016.11.007

Jenkins, R. 2009. The ways and means of power: efficacy and resources. Pages 140-156 in S. R. Clegg and M. Haugaard, editors. The SAGE handbook of power. SAGE, Thousand Oaks, California, USA. https://doi.org/10.4135/9780857021014.n8

Leach, M., R. Mearns, and I. Scoones. 1999. Environmental entitlements: dynamics and institutions in community-based natural resource management. World Development 27 (2):225-247.

Lele, S., O. Springate-Baginski, R. Lakerveld, D. Deb, and P. Dash. 2013. Ecosystem services: origins, contributions, pitfalls, and alternatives. Conservation and Society 11(4):343-358. https:// doi.org/10.4103/0972-4923.125752

Lewin, A. Y., and H. W. Volberda. 2003. Preface. Journal of Management Studies 40(8):2109-2110. https://doi.org/10.1046/ j.1467-6486.2003.t01-2-00413 2.x
Locatelli, B., C. Pavageau, E. Pramova, and M. Di Gregorio. 2015. Integrating climate change mitigation and adaptation in agriculture and forestry: opportunities and trade-offs. Wiley Interdisciplinary Reviews: Climate Change 6(6):585-598. https:// doi.org/10.1002/wcc.357

Mangiafico, S. 2018. rcompanion: functions to support extension education program evaluation. R Foundation for Statistical Computing, Vienna, Austria. [online] URL: https://cran.rproject.org/web/packages/rcompanion/index.html

Martinez-Harms, M. J., B. A. Bryan, P. Balvanera, E. A. Law, J. R. Rhodes, H. P. Possingham, and K. A. Wilson. 2015. Making decisions for managing ecosystem services. Biological Conservation 184:229-238. https://doi.org/10.1016/j.biocon.2015.01.024

Mason, J. 2002. Qualitative researching. Second revised edition. SAGE, London, UK.

Mearns, R. 1996. Environmental entitlements: pastoral natural resource management in Mongolia. Cahiers des Sciences Humaines 32(1):105-131.

Meyer, D., A. Zeileis, K. Hornik, F. Gerber, and M. Friendly. 2017. vcd: visualizing categorical data. $\mathrm{R}$ Foundation for Statistical Computing, Vienna, Austria. [online] URL: https:// cran.r-project.org/package $=$ ved

Millennium Ecosystem Assessment. 2005. Ecosystems and human well-being: current state and trends. Findings of the Condition and Trends Working Group of the Millennium Ecosystem Assessment. Island, Washington, D.C., USA.

Ministerio del Ambiente (MINAM). 2015. Mapa nacional de cobertura vegetal : Memoria descriptiva. Dirección General de Evaluación, Valoración y Financiamiento del Patrimonio Natural, MINAM, Lima, Peru.

Olsson, P., C. Folke, and F. Berkes. 2004. Adaptive comanagement for building resilience in social-ecological systems. Environmental Management 34(1):75-90. https://doi.org/10.1007/s00267-003-0101-7

Ostrom, E. 1990. Governing the commons: the evolution of institutions for collective action. Cambridge University Press, Cambridge, UK. https://doi.org/10.1017/CBO9780511807763

Palomo, I., M. R. Felipe-Lucia, E. M. Bennett, B. Martín-López, and U. Pascual. 2016. Disentangling the pathways and effects of ecosystem service co-production. Pages 245-283 in G. Woodward and D. A. Bohan, editors. Ecosystem services: from biodiversity to society, Part 2. Advances in Ecological Research, Volume 54. Academic, London, UK. https://doi.org/10.1016/bs.aecr.2015.09.003

Pitkin, H. F. 1972. Wittgenstein and justice. University of California Press, Berkeley, California, USA.

Primmer, E., P. Jokinen, M. Blicharska, D. N. Barton, R. Bugter, and M. Potschin. 2015. Governance of ecosystem services: a framework for empirical analysis. Ecosystem Services 16:158-166. https://doi.org/10.1016/j.ecoser.2015.05.002

Programa de las Naciones Unidas para el Desarrollo (PNUD). 2013. Informe sobre Desarrollo Humano Perú 2013. PNUD, Lima, Peru.

Reed, M. S., A. Graves, N. Dandy, H. Posthumus, K. Hubacek, J. Morris, C. Prell, C. H. Quinn, and L. C. Stringer. 2009. Who's in and why? A typology of stakeholder analysis methods for 
natural resource management. Journal of Environmental Management 90(5):1933-1949. https://doi.org/10.1016/j. jenvman.2009.01.001

Sánchez-Medina, A. J., L. Romero-Quintero, and S. SosaCabrera. 2014. Environmental management in small and medium-sized companies: an analysis from the perspective of the theory of planned behavior. PLOS ONE 9(2):e88504. https://doi. org/10.1371/journal.pone.0088504

Schlager, E., and E. Ostrom. 1992. Property-rights regimes and natural resources: a conceptual analysis. Land Economics 68 (3):249-262. https://doi.org/10.2307/3146375

Schlosberg, D. 2003. The justice of environmental justice: reconciling equity, recognition, and participation in a political movement. Pages 77-106 in A. Light and A. De-Shalit, editors. Moral and political reasoning in environmental practice. MIT Press, Cambridge, Massachusetts, USA.

Schröter, M., K. H. Stumpf, J. Loos, A. P. E. van Oudenhoven, A. Böhnke-Henrichs, and D. J. Abson. 2017. Refocusing ecosystem services towards sustainability. Ecosystem Services 25:35-43. https://doi.org/10.1016/j.ecoser.2017.03.019

Scoones, I. 1998. Sustainable rural livelihoods: a framework for analysis. Institute of Development Studies (IDS) Working Paper 72. IDS, Brighton, UK.

Sen, A. 1984. Resources, values, and development. Harvard University Press, Cambridge, Massachusetts, USA.

Servicio Nacional de Áreas Naturales Protegidas por el Estado (SERNANP). 2016. Diagnóstico Plan Maestro del Santuario Nacional de Ampay 2015-2019. SERNANP, Lima, Peru.

Sikor, T., editor. 2013. The justices and injustices of ecosystem services. Routledge, London, UK. https://doi.org/10.4324/9780203395288

Solano Cornejo, D. 2015. Estrategia de comunicación y sensibilización para promover la participación ciudadana en los mecanismos de RSE informe final de consultoría. Programa Bosques Andinos, Abancay, Peru.

Spangenberg, J. H., C. von Haaren, and J. Settele. 2014. The ecosystem service cascade: further developing the metaphor. Integrating societal processes to accommodate social processes and planning, and the case of bioenergy. Ecological Economics 104:22-32. https://doi.org/10.1016/j.ecolecon.2014.04.025

Suwarno, A., L. Hein, and E. Sumarga. 2016. Who benefits from ecosystem services? A case study for Central Kalimantan, Indonesia. Environmental Management 57(2):331-344. https:// doi.org/10.1007/s00267-015-0623-9

Turkelboom, F., M. Leone, S. Jacobs, E. Kelemen, M. GarcíaLlorente, F. Baró, M. Termansen, D. N. Barton, P. Berry, E. Stange, M. Thoonen, Á. Kalóczkai, A. Vadineanu, A. J. Castro, B. Czúcz, C. Röckmann, D. Wurbs, D. Odee, E. Preda, E. GómezBaggethun, G. M. Rusch, G. M. Pastur, I. Palomo, J. Dick, J. Casaer, J. van Dijk, J. A. Priess, J. Langemeyer, J. Mustajoki, L. Kopperoinen, M. J. Baptist, P. L. Peri, R. Mukhopadhyay, R. Aszalós, S. B. Roy, S. Luque, and V. Rusch. 2018. When we cannot have it all: ecosystem services trade-offs in the context of spatial planning. Ecosystem Services 29C:566-578. https://doi. org/10.1016/j.ecoser.2017.10.011
Turner, M. G., D. C. Donato, and W. H. Romme. 2013. Consequences of spatial heterogeneity for ecosystem services in changing forest landscapes: priorities for future research. Landscape Ecology 28(6):1081-1097. https://doi.org/10.1007/ $\underline{\text { s10980-012-9741-4 }}$

Unidad Ejecutora Pro Desarrollo Apurímac. 2010. Caracterización ecológica económica de la microcuenca Mariño. Gobierno Regional de Apurímac, Abancay, Peru.

Vallet, A., B. Locatelli, H. Levrel, S. Wunder, R. Seppelt, R. J. Scholes, and J. Oszwald. 2018. Relationships between ecosystem services: comparing methods for assessing tradeoffs and synergies. Ecological Economics 150:96-106. https://doi. org/10.1016/j.ecolecon.2018.04.002

White, C., and C. Costello. 2011. Matching spatial property rights fisheries with scales of fish dispersal. Ecological Applications 21 (2):350-362. https://doi.org/10.1890/09-1188.1

Wolff, S., C. J. E. Schulp, and P. H. Verburg. 2015. Mapping ecosystem services demand: a review of current research and future perspectives. Ecological Indicators 55:159-171. https://doi. org/10.1016/j.ecolind.2015.03.016

Yandle, T. 2007. Understanding the consequences of property rights mismatches: a case study of New Zealand's marine resources. Ecology and Society 12(2):27. https://doi.org/10.5751/ ES-02181-120227 


\section{Appendix 1. List of ecosystem services used in the workshop.}

We used a list of ES adapted from the Millennium Ecosystem Assessment and CICES typologies (MEA 2005, Haines-Young and Potschin 2013). During a workshop, participants were given 10 stickers each and asked to distribute them over the ES list to spot the ES they considered the most at stake (i.e. beneficial and threatened). Participants could give more than one sticker to any ES.

Table A1.1. List of ES used in the workshop and total number of stickers each ES received from participants. ES in bold correspond to selected ones.

$\begin{array}{ll}\text { ES description } & \begin{array}{l}\text { Number of } \\ \text { stickers }\end{array}\end{array}$

\section{Provisioning services: Nutrition and health}

$\begin{array}{ll}\text { Cultivated crops (cereals, fruits, vegetables, etc.) } & 16\end{array}$

Reared animals and their outputs (meat, dairy products, eggs) 5

$\begin{array}{ll}\text { Other reared animals and their outputs (apiculture, aquaculture) } & 0\end{array}$

Food from wild animals (hunting or fishing) 0

Food from wild plants (aromatic plants, mushrooms, fruit, etc.) 4

Medicinal and genetic resources (leaves, barks, etc.) 0

\section{Provisioning services: Materials}

Timber $\quad 2$

Fibers (cotton, hemp, silk, wool, etc.) 0

Biochemical products, natural medicines, pharmaceutical products $\quad 0$

Genetic material (for bioprospecting, industry, etc.) 9

$\begin{array}{ll}\text { Feed for animals (grass, fodder, etc.) } & 0\end{array}$

\section{Provisioning services: Energy}

$\begin{array}{ll}\text { Firewood and charcoal } & 2\end{array}$

Animal outputs for energy (excrement, fats, oils) 0

Biofuels (cane for bioethanol, corn for biofuel, etc.) 0

\section{Regulating services: Control of soil and water fluxes}

$\begin{array}{ll}\text { Control of soil sheet erosion rates (laminar erosion) } & 15\end{array}$

Control of rill and gully soil erosion rates (linear erosion) 0

Buffering and attenuation of mass movement (mass erosion) $\quad 8$

$\begin{array}{ll}\text { Control of bank erosion } & 0\end{array}$

$\begin{array}{ll}\text { Regulation of surface water flows (river base flow, lake levels) } & 17\end{array}$

$\begin{array}{ll}\text { Regulation of groundwater flows (aquifer levels) } & 9\end{array}$

$\begin{array}{ll}\text { Flood control } & 0\end{array}$ 


\section{Regulating services: Regulation of physical, chemical, biological conditions}

Global climate regulation by reduction of greenhouse gas concentrations 0

$\begin{array}{ll}\text { Micro and regional climate regulation } & 11\end{array}$

$\begin{array}{ll}\text { Regulation of air quality } & 2\end{array}$

$\begin{array}{ll}\text { Pollination and seed dispersal } & 7\end{array}$

Pest and disease control

\section{Regulating services: Mediation of waste, toxics and other nuisances}

Water purification

Decontamination of soils and sediments by micro-organisms, algae, plants, and animals

Sequestration of toxics by micro-organisms, algae, plants, animals or soils $\quad 0$

$\begin{array}{ll}\text { Waste water treatment by soils or vegetation } & 0\end{array}$

$\begin{array}{ll}\text { Dilution of toxics by freshwater or the atmosphere } & 0\end{array}$

\section{Cultural services: Physical and experiential interactions with natural environment}

Ecotourism (watching plants and animals) 12

Recreation (hiking, mountaineering, leisure fishing and hunting) 5

$\begin{array}{ll}\text { Aesthetic values (scenic beauty) } & 0\end{array}$

Artistic inspiration 4

$\begin{array}{ll}\text { Education and training (studying nature) } & 7\end{array}$

\section{Cultural services: Spiritual, symbolic and other interactions with natural environment}

Cultural heritage or historical knowledge $\quad 2$

Spiritual and religious values (sacred places, plants and animals) 5

Identity, sense of place $\quad 3$

Existence, option or bequest value (important to others and future generations) 4

After participants distributed their stickers on the list, a general discussion took place to decide upon the final list of prioritized ES.

Participants suggested to merge "Cultivated crops" (16 stickers) with "Reared animals and their outputs" (5 stickers) into a category named "Agricultural production". They also merged "Regulation of surface water" (17 stockers) with "Regulation of groundwater flow" (9 stickers) into a category named "Regulation of water quantity".

They also decided that the "Ecotourism" ES should not be limited to animal and plant watching, but also include recreation activities, because tourists practice such activities simultaneously with wildlife and landscape observation. 
The "Genetic material" ES was reformulated as "Medicinal plants" after some participants underlined that there were no industrial or pharmaceutical uses in the region. All participants agreed that current uses corresponded more to the "Medicinal and genetic resources" category from the "Provisioning services: Nutrition and health" section.

And finally, the absence of knowledge on local climate regulation by ecosystems (including in the urban area) led participants to include "Global climate regulation by reduction of greenhouse gas concentrations" instead of "Micro and regional climate regulation".

As a result, the final list included the following ES:

- Agricultural production

- Medicinal plants

- Water purification (labeled "Water quality")

- Regulation of water quantity (labeled "Water quantity")

- Buffering and attenuation of mass movement (labeled "Mass erosion")

- Control of soil sheet erosion rates (labeled "Sheet erosion")

- Global climate regulation by reduction of greenhouse gas concentrations (labeled "Global climate")

- Ecotourism

\section{References}

Haines-Young, R., and M. Potschin. 2013. Common International Classification of Ecosystem Services (CICES) : Consultation on Version 4.

MEA. 2005. Ecosystems and human well-being: current state and trends: findings of the Condition and Trends Working Group of the Millennium Ecosystem Assessment. Page (R. M. Hassan, R. J. Scholes, and N. Ash, editors). Island Press, Washington, DC. 


\section{Appendix 2. List of stakeholders.}

Table A2.1. Description and characteristics of the stakeholders selected for the analysis. Num. Int.: Number of interviews. (*) indicates the interviews that were conducted with multiple participants.

\begin{tabular}{|c|c|c|c|c|}
\hline $\begin{array}{l}\text { Stakeholder } \\
\text { name }\end{array}$ & Scale & Sector & Description & $\begin{array}{l}\text { Num. } \\
\text { Inter. }\end{array}$ \\
\hline Fish farmers & Local & Businesses & Small-scale and familiar fish farmers & 1 \\
\hline $\begin{array}{l}\text { Water-related } \\
\text { businesses }\end{array}$ & Local & Businesses & $\begin{array}{l}\text { Companies using water for their activities (distillers, } \\
\text { slaughterhouse, car wash, public swimming pools) }\end{array}$ & 2 \\
\hline Emolienteros & Local & Businesses & $\begin{array}{l}\text { Vendors selling herbal beverages with medicinal } \\
\text { properties }\end{array}$ & 1 \\
\hline Plant traders & Local & Businesses & $\begin{array}{l}\text { People harvesting and selling medicinal plants in local } \\
\text { markets }\end{array}$ & $1 *$ \\
\hline $\begin{array}{l}\text { Transport } \\
\text { companies }\end{array}$ & Local & Businesses & $\begin{array}{l}\text { Companies proving transportation services (taxis, bus, } \\
\text { freight carrier) }\end{array}$ & $1^{*}$ \\
\hline $\begin{array}{l}\text { Hotels and } \\
\text { Restaurants }\end{array}$ & Local & Businesses & Hotels and restaurant & 1 \\
\hline $\begin{array}{l}\text { Ecotourism } \\
\text { businesses }\end{array}$ & Local & Businesses & $\begin{array}{l}\text { Businesses providing services related to ecotourism (travel } \\
\text { agencies, guides, muleteers, rentals for extreme sports } \\
\text { such as paraglider) }\end{array}$ & 2 \\
\hline $\begin{array}{l}\text { Natural } \\
\text { resources based } \\
\text { businesses }\end{array}$ & Local & Businesses & $\begin{array}{l}\text { Businesses using natural resources for economic activities } \\
\text { (such as craftsmen or brickmakers) }\end{array}$ & 1 \\
\hline $\begin{array}{l}\text { Agroindustrial } \\
\text { companies }\end{array}$ & Local & Businesses & $\begin{array}{l}\text { Food industries (dairy products, honey, traditional, } \\
\text { noodles) }\end{array}$ & $1 *$ \\
\hline $\begin{array}{l}\text { Urban } \\
\text { population }\end{array}$ & Local & Civil Society & $\begin{array}{l}\text { Population that lives in urban areas of Abancay and } \\
\text { Tamburco }\end{array}$ & 2 \\
\hline $\begin{array}{l}\text { Rural } \\
\text { population }\end{array}$ & Local & Civil Society & Population living in rural settlements & 3 \\
\hline Communities & Local & Civil Society & $\begin{array}{l}\text { Rural organizations: communities (formally recognized } \\
\text { legal personality with communal property rights) and } \\
\text { sectors (group of people with individual rights) }\end{array}$ & 2 \\
\hline JASS & Local & Civil Society & $\begin{array}{l}\text { Community-managed organizations that provide sanitation } \\
\text { and drinking water services in rural areas }\end{array}$ & 1 \\
\hline JUDRAB & Local & Civil Society & $\begin{array}{l}\text { Water user associations managed by communities and that } \\
\text { provide irrigation water service }\end{array}$ & 1 \\
\hline $\begin{array}{l}\text { Ecotourism } \\
\text { associations }\end{array}$ & Local & Civil Society & Associations of hikers or bikers & 1 \\
\hline $\begin{array}{l}\text { Abancay } \\
\text { Municipality }\end{array}$ & Local & Public sector & Municipality of Abancay & $2 *$ \\
\hline $\begin{array}{l}\text { Tamburco } \\
\text { Municipality }\end{array}$ & Local & Public sector & Municipality of Tamburco & 1 \\
\hline EMUSAP & Local & Public sector & $\begin{array}{l}\text { Water utility (public company) responsible for providing } \\
\text { drinking water and sanitation services in urban areas of } \\
\text { Abancay and Tamburco }\end{array}$ & 1 \\
\hline $\begin{array}{l}\text { Electro Sur } \\
\text { Este }\end{array}$ & Sub-national & Businesses & $\begin{array}{l}\text { Electricity utility (private company) responsible for the } \\
\text { production and distribution of electric power in various } \\
\text { regions of southern Peru }\end{array}$ & 1 \\
\hline CEDES & Sub-national & NGO & Center for studies and social development & 1 \\
\hline IIDA & Sub-national & NGO & Institute for research and Andean development & 1 \\
\hline CICCA & Sub-national & NGO & Centre for research and rural training & 1 \\
\hline $\begin{array}{l}\text { RGA - Civil } \\
\text { defense }\end{array}$ & Sub-national & Public sector & Regional office for civil defense (Regional Government) & 1 \\
\hline $\begin{array}{l}\text { Mariño micro- } \\
\text { catchment } \\
\text { Project }\end{array}$ & Sub-national & Public sector & $\begin{array}{l}\text { Project aiming at improving agricultural production in the } \\
\text { Mariño watershed through the integrated management of } \\
\text { water resources }\end{array}$ & 1 \\
\hline $\begin{array}{l}\text { RGA - } \\
\text { Economic } \\
\text { Development }\end{array}$ & Sub-national & Public sector & $\begin{array}{l}\text { Regional office for economic development (Regional } \\
\text { Government) }\end{array}$ & 4 \\
\hline
\end{tabular}




\begin{tabular}{|c|c|c|c|c|}
\hline $\begin{array}{l}\text { RGA - } \\
\text { Infrastructure }\end{array}$ & Sub-national & Public sector & Regional office for infrastructures (Regional Government) & 3 \\
\hline $\begin{array}{l}\text { RGA - } \\
\text { Planning and } \\
\text { Budget }\end{array}$ & Sub-national & Public sector & $\begin{array}{l}\text { Regional office for planning and budget (Regional } \\
\text { Government) }\end{array}$ & 1 \\
\hline $\begin{array}{l}\text { RGA - Natural } \\
\text { resources }\end{array}$ & Sub-national & Public sector & $\begin{array}{l}\text { Regional office for environment and natural resources } \\
\text { (Regional Government) }\end{array}$ & 1 \\
\hline $\begin{array}{l}\text { RGA - Social } \\
\text { Development }\end{array}$ & Sub-national & Public sector & $\begin{array}{l}\text { Regional office for social development (Regional } \\
\text { Government) }\end{array}$ & 1 \\
\hline Tourists & $\begin{array}{l}\text { National and } \\
\text { International }\end{array}$ & Civil Society & National or international tourists & $1 *$ \\
\hline PREDES & $\begin{array}{l}\text { National and } \\
\text { International }\end{array}$ & NGO & Centre for Disaster Prevention and Studies & 1 \\
\hline $\begin{array}{l}\text { Andean Forests } \\
\text { program }\end{array}$ & $\begin{array}{l}\text { National and } \\
\text { International }\end{array}$ & NGO & $\begin{array}{l}\text { Initiative from the Swiss Agency for Development and } \\
\text { Cooperation aiming at promoting sustainable management } \\
\text { of Andean forests }\end{array}$ & 1 \\
\hline CESAL & $\begin{array}{l}\text { National and } \\
\text { International }\end{array}$ & NGO & Organization promoting integrated development models & $1 *$ \\
\hline CARITAS & $\begin{array}{l}\text { National and } \\
\text { International }\end{array}$ & NGO & $\begin{array}{l}\text { Catholic organization aiming at improving human } \\
\text { development and responding to humanitarian emergencies }\end{array}$ & 1 \\
\hline IDMA & $\begin{array}{l}\text { National and } \\
\text { International }\end{array}$ & NGO & Institute for Development and Environment & 1 \\
\hline INDECI & $\begin{array}{l}\text { National and } \\
\text { International }\end{array}$ & Public sector & National Institute for Civil Defense & 1 \\
\hline INGEMMET & $\begin{array}{l}\text { National and } \\
\text { International }\end{array}$ & Public sector & Geological Mining and Metallurgical Institute & 1 \\
\hline CENEPRED & $\begin{array}{l}\text { National and } \\
\text { International }\end{array}$ & Public sector & $\begin{array}{l}\text { National Centre for the Estimation, Prevention and } \\
\text { Reduction of Disaster Risk }\end{array}$ & 1 \\
\hline ANA & $\begin{array}{l}\text { National and } \\
\text { International }\end{array}$ & Public sector & National Water Authority & $2 *$ \\
\hline SENAMHI & $\begin{array}{l}\text { National and } \\
\text { International }\end{array}$ & Public sector & National Service for Meteorology and Hydrology & 1 \\
\hline Provias & $\begin{array}{l}\text { National and } \\
\text { International }\end{array}$ & Public sector & National road authority & 1 \\
\hline PRODERN & $\begin{array}{l}\text { National and } \\
\text { International }\end{array}$ & Public sector & $\begin{array}{l}\text { Program for Sustainable Economic Development and } \\
\text { Strategic Management of Natural Resources }\end{array}$ & 1 \\
\hline OEFA & $\begin{array}{l}\text { National and } \\
\text { International }\end{array}$ & Public sector & Agency for Environmental Assessment and Enforcement & 1 \\
\hline $\begin{array}{l}\text { Public } \\
\text { prosecutor }\end{array}$ & $\begin{array}{l}\text { National and } \\
\text { International }\end{array}$ & Public sector & Public prosecutor specialized in environmental matters & 1 \\
\hline SERNANP & $\begin{array}{l}\text { National and } \\
\text { International }\end{array}$ & Public sector & National Service of Natural Protected Areas & 1 \\
\hline $\begin{array}{l}\text { Peruvian } \\
\text { ombudsman }\end{array}$ & $\begin{array}{l}\text { National and } \\
\text { International }\end{array}$ & Public sector & Office of Public Defender & $1 *$ \\
\hline SERFOR & $\begin{array}{l}\text { National and } \\
\text { International }\end{array}$ & Public sector & National Forest Service & 1 \\
\hline Police & $\begin{array}{l}\text { National and } \\
\text { International }\end{array}$ & Public sector & Police specialized in environmental matters & 1 \\
\hline FONCODES & $\begin{array}{l}\text { National and } \\
\text { International }\end{array}$ & Public sector & Social Development and Compensation Fund Project & $1 *$ \\
\hline AgroRural & $\begin{array}{l}\text { National and } \\
\text { International }\end{array}$ & Public sector & National program promoting rural agrarian development & 1 \\
\hline SENASA & $\begin{array}{l}\text { National and } \\
\text { International }\end{array}$ & Public sector & National Agricultural Health Service & 1 \\
\hline $\begin{array}{l}\text { Sierra } \\
\text { Exportadora }\end{array}$ & $\begin{array}{l}\text { National and } \\
\text { International }\end{array}$ & Public sector & $\begin{array}{l}\text { National program that promote the exportation of } \\
\text { economic activities from Peruvian Andes }\end{array}$ & $1^{*}$ \\
\hline
\end{tabular}




\section{Appendix 3. Interview guide.}

\section{Description of the stakeholder or institution activities}

What are the activities that you (or your institution) carry out and that are linked to the environment or the natural resources of the Mariño watershed?

Are you taking part in the management of ecosystems in the watershed? If yes, how do you contribute to their management (monitoring, legislation, inspection, access control, technical assistance)?

Do you participate in any platform about the environment or natural resources of the watershed? Could you list the actors and institutions you interact with through this platform?

\section{ES Benefits}

This is a list of 8 ecosystem services (i.e. benefits from nature). Could you identify the ones that provide benefits (material or not) to you?

- Agricultural production

- Medicinal plants

- Water purification

- Regulation of water quantity

- Buffering and attenuation of mass movement

- Control of soil sheet erosion rates

- Global climate regulation by reduction of greenhouse gas concentrations

- Ecotourism

For each of the ES indicated, please answer the following questions ${ }^{1}$ :

- What kind of benefits does this ES bring?

- Is there any institution that regulates negatively (e.g. restricts, limits) or positively (e.g. favors, facilitates) the way you benefit from this ES? How?

\section{ES management}

In the same list of ecosystem services, could you identify the ones that you manage?

For each of the ES indicated, please answer the following questions ${ }^{2}$ :

- How do you manage this ES? Through what direct activities? Through what indirect actions (monitoring, inspection, technical assistance, legislation such as agricultural quota or order or other)?

- Do you have a problem with other institutions or actors with regards to the management of this ES? For example, in the last year, with which institutions or social groups have you had problems or conflicts?

- Do you participate in any work platform with other institutions about this ES and its management?

\footnotetext{
${ }^{1}$ The questions were adapted to each ES and examples were provided if the interviewee had trouble understanding them.

${ }^{2}$ The questions were adapted to each ES and examples were provided if the interviewee had trouble understanding them.
} 


\section{Appendix 4. Detailed qualitative results.}

\section{ES Beneficiaries}

Agricultural production benefited four stakeholder types, all at the local scale: urban populations (for subsistence), rural populations (for subsistence and income generation), rural communities (for incomes from collective plantations) and agro-industries (for profit).

Similarly, medicinal plants benefited to four stakeholder types from local scale: plant traders (for personal use and income), emolienteros (herbal beverage sellers with mobile stalls) (for profit), rural population (personal use) and ecotourism business (as some visitors are eager to learn about medicinal plants).

Water quality benefited several stakeholder types: rural and urban populations (health benefits), communities, companies or organizations providing drinking (EMUSAP in urban areas, JASS in communities) and irrigation water (JUDRAB) for the reduced cost of water treatment, as well as stakeholders from the business sector using water their economic activities (fish farmers, water-related businesses, hotels and restaurants, agro-industries) for the better quality of water and the reduced cost of additional water-treatment operations they implement.

Water quantity benefited diverse stakeholder types, including rural and urban populations, communities, companies or organizations providing drinking and irrigation water, and businesses using water for their activities (e.g. fish farms, agro-industries, hotels and restaurants).

Mass erosion benefited many stakeholders from different scales (local to national): Urban and rural populations, communities, tourists and ecotourism associations, as well as companies or organizations providing drinking and irrigation water (their water infrastructures are often destroyed during landslides), businesses such as fish farmers, transport companies or Electro Sur Este (infrastructures), public institutions in charge of civil defense after hazard, such as INDECI, Regional government, Provias (cost of intervention).

Sheet erosion benefited rural population and communities (conservation of soil for agricultural production), businesses using water for their activities, such as fish farmers, Electro Sur Este and agro-industries (sediments in water negatively impact their business) and companies or organizations providing drinking and irrigation water (extra cost of water treatment).

Global climate regulation benefited to urban and rural population (heat and droughts control, maintenance of agricultural production), companies or organizations providing drinking water (regulation of water availability), stakeholder from business sector using water for their activities (fish farmers, water-related businesses, hotels and restaurants, agro-industries), stakeholders from business sector that are dependent on water availability for their activities (plant traders, ecotourism businesses and SERNANP), as well as public institutions in charge of civil defense after hazard (including droughts or heat waves), such as INDECI and the regional government (cost of intervention).

Ecotourism benefited tourists, local hiking or biking clubs, as well as businesses and individuals providing services to tourists (nature guides, tourism and transportation companies, hotels, 
restaurants, and communities or individuals providing housing and food services) and the National Service of Natural Protected Areas for the incomes generated by entrance fees

\section{ES managers}

Table A4.1. Examples of management activities for each of the eight selected ES. This list is not exhaustive, but rather illustrative.

Direct: Act directly
Indirect: Coordinate and supervise (CS), Provide

finance (PF), Provide knowledge and skills (PK),

Provide supplies and materials (PS), Regulate ES flows

(RF), Restrict ES degradation (RD)

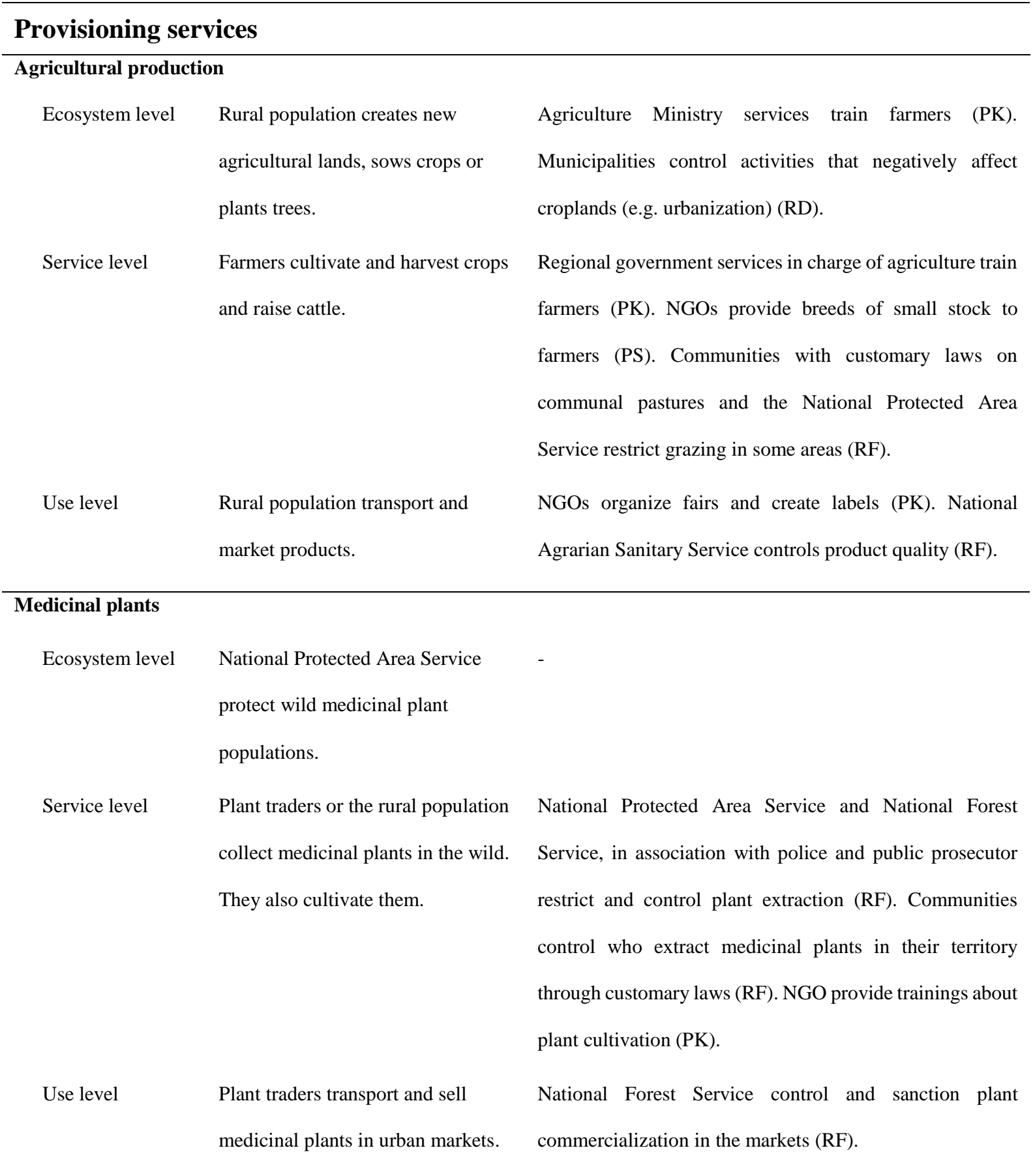




\section{Regulating services}

\section{Water quality}

Ecosystem level

Rural population and communities protect wetlands with fences.

Communal organizations providing

drinking and irrigation water

reforest upper watershed.

Service level

Use level

\begin{abstract}
NGOs and regional government
build water treatment

infrastructures. Companies or

organizations providing drinking
\end{abstract}

water treat water and distribute it.
Municipality protect upper watershed through legislation (RD). NGOs and local institutions provide supplies and materials to reforest upper watershed or protect wetlands (PS). International cooperation and national programs provide finance to NGOs and local institutions (PF). NGOs, national programs, and public institutions provide technical supervision and trainings to rural population (PK).

Municipality, National Water Authority and regional government in association with police and public prosecutor control, monitor and sanction water contamination (RD). Community enforce customary law (RD). NGOs provide supplies and materials to build infiltration ditches (PS) as well as technical supervision and trainings (PK). National Water Authority and regional government raise awareness about solid wastes and wastewater management (PK).

Municipalities and regional government supervise communal organizations providing drinking water (CS) and train them (PK). Companies or organizations providing drinking water and regional government monitor water quality and restrict uses depending on quality (RF). National Water Authority and regional government give permits to some specific water uses (RF).

\footnotetext{
Water quantity

Ecosystem level Rural populations or irrigation NGOs train rural populations and communities to wetland committees reforest upper management (PK). Municipalities define protected areas to watershed. Communities protect protect water resources (RD).

wetlands with fences.
} 
Service level

small-scale dams to improve water

regulation.

Use level

Irrigation committees manage

canals to transport water. Regional

government and NGOs build water

infrastructure for water distribution.
NGOs train communities and rural populations to construct dams (PK) and provide materials for the construction of dams (PS).

National Water Authority grants water licenses (RF). Companies or associations charge fees for irrigation and drinking water (RF). Environment Ministry supervises stakeholders using water (CS).

\begin{tabular}{lll}
\hline Mass erosion & Public institutions in charge of & NGOs provide training about public inversion to prevent \\
Ecosystem level & natural hazards (PK). Police and public prosecutor sanction \\
& reforest along roads. & illegal activities that generate mass erosion (deforestation, \\
& mining, etc.) (RD) \\
Service level & - & Municipality and regional government control city \\
& expansion through zoning and construction licenses (RF). \\
& National Water Authority identifies dangerous river \\
& margins (RF). National and regional institutions in charge \\
& of civil defense monitor mass erosion events (PK). NGOs, \\
& municipalities as well as national and regional institutions \\
& in charge of civil defense raise population awareness (PK). \\
& Regional government animate a platform on risk \\
& management (CS).
\end{tabular}

\section{Sheet erosion}

Ecosystem level

National programs and regional government bring supplies and materials to improve vegetation cover (PS) and train communities and rural farmers to sustainable land cover management (PK).

Service level

Farmers adopt soil conservation NGOs and national programs provide trainings and agricultural practices (spray or drip technical assistance for the construction of terraces, irrigation, terraces, etc.) infiltration ditches, soil management in agriculture (PK).

Use level 


\section{Global climate}

Ecosystem level Urban population and civil society associations plant trees for mitigating climate change.

Municipalities and regional government monitor and sanction $\mathrm{CO}_{2}$ emissions (RD). Regional government and businesses bring supplies and materials to reforest areas (PS). National Protected Area Service, National Forest Service and regional government raise population awareness about climate change and train rural population to climate change mitigation (PK). NGOs and regional government finance reforestation programs (PF).

Service level

Use level

\section{Cultural services}

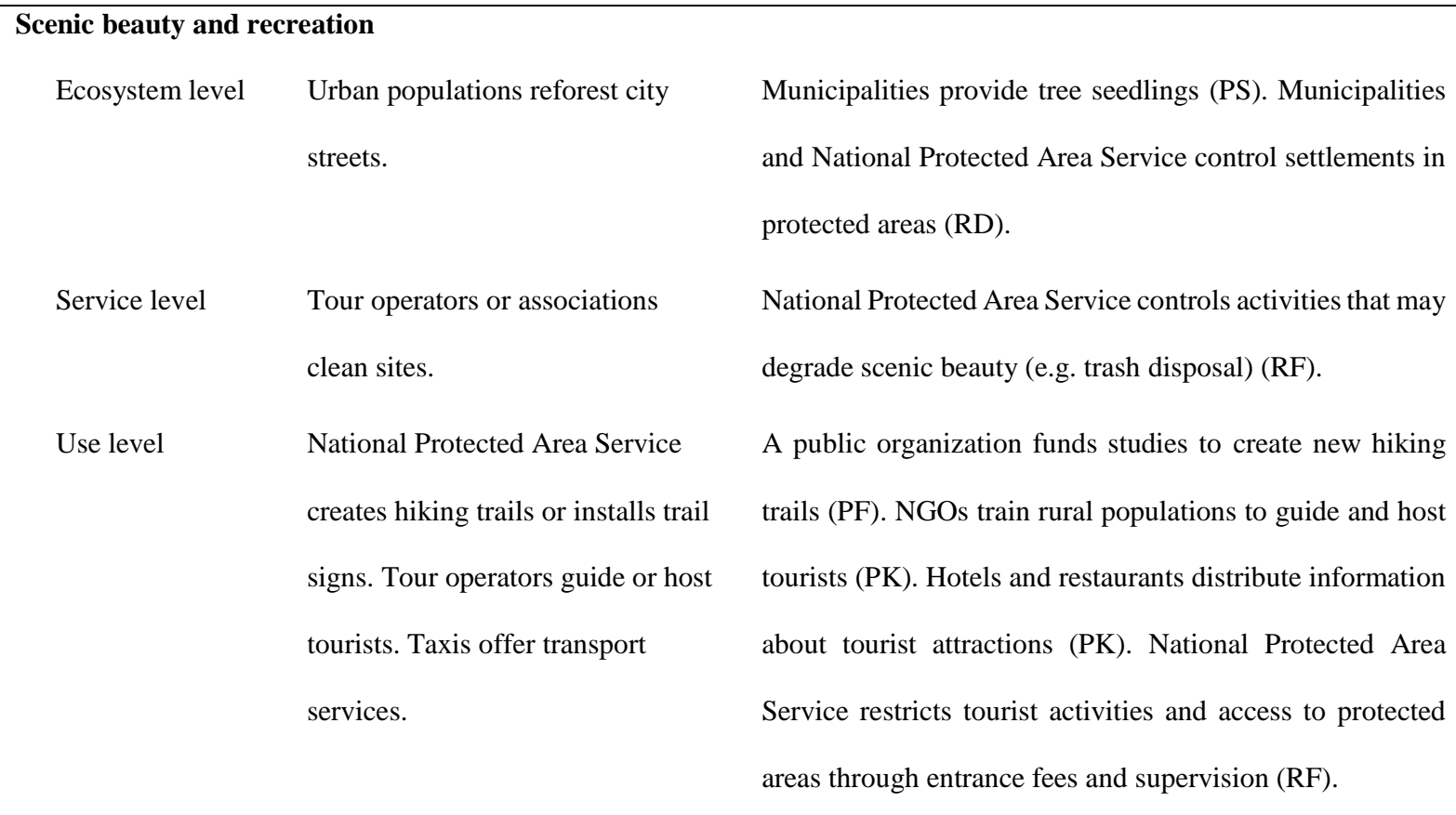




\section{Appendix 5. Results of permutation tests.}

Mosaic plots allow the visualization of contingency tables and independence tests (Friendly 2017). Box colors show the outcome of the independence test using Pearson residuals as the test statistic. Blue boxes indicate positive residuals (i.e. it is more likely to find stakeholders in this category than expected) and red boxes indicate negative residuals. Blue gradients (or red gradients) indicate residuals with absolute values exceeding critical values (i.e. significant differences at the $99 \%, 95 \%$ and $90 \%$ percentiles in the distribution of absolute Pearson residuals). For sake of simplicity, boxes with absolute residuals below the critical value of $90 \%$ are white. The plots were drawn with the vcd package in $\mathrm{R}$ and the distribution of absolute Pearson residuals were calculated with the function coindep_test of this package ( $R$ Core Team 2016, Meyer et al. 2017).

A

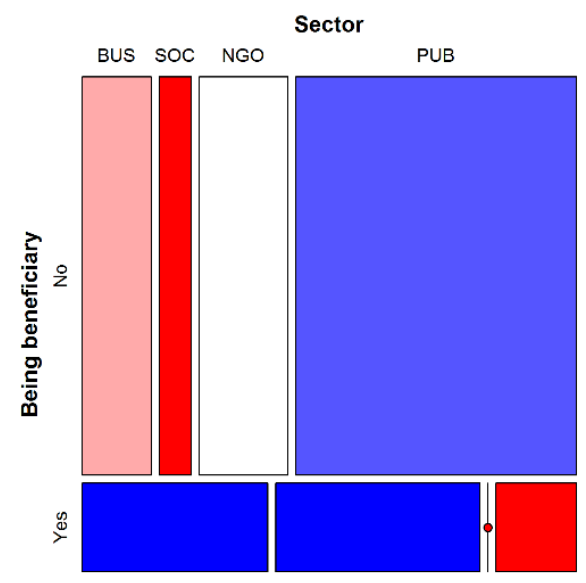

B

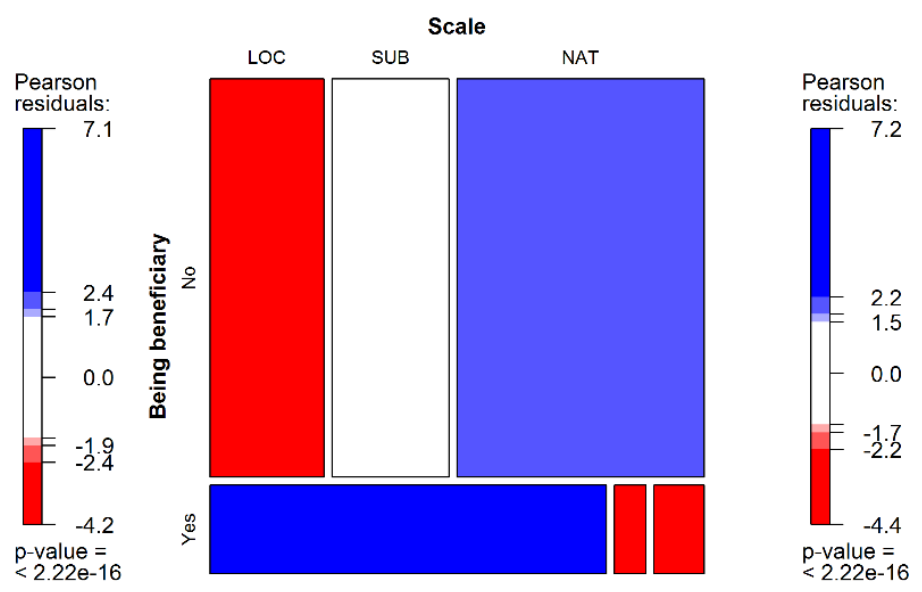

Figure A5.1. Mosaic plots of the frequency of being/not being beneficiary of ES for different groups of stakeholders. Each box is associated with a binary variable in left list (Yes beneficiary, and No beneficiary) and stakeholders groups in top list (Sector in panel A - BUS=Business, SOC=Civil Society, NGO=Non-Governmental Organizations, PUB=Public Sector - and scale of influence in panel B - LOC=Local, SUB=Sub-national, NAT=National and International). The height of a box is proportional to the number of observations for being/not being beneficiary of ES. The width of a box is proportional to the number of stakeholders in each group. 
A

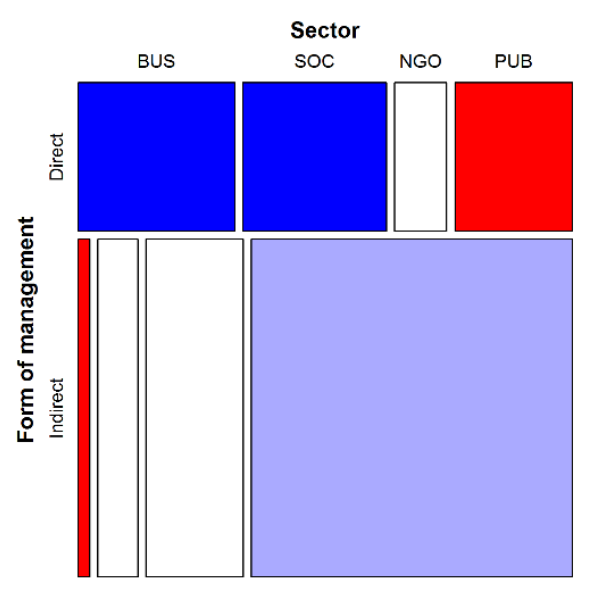

B

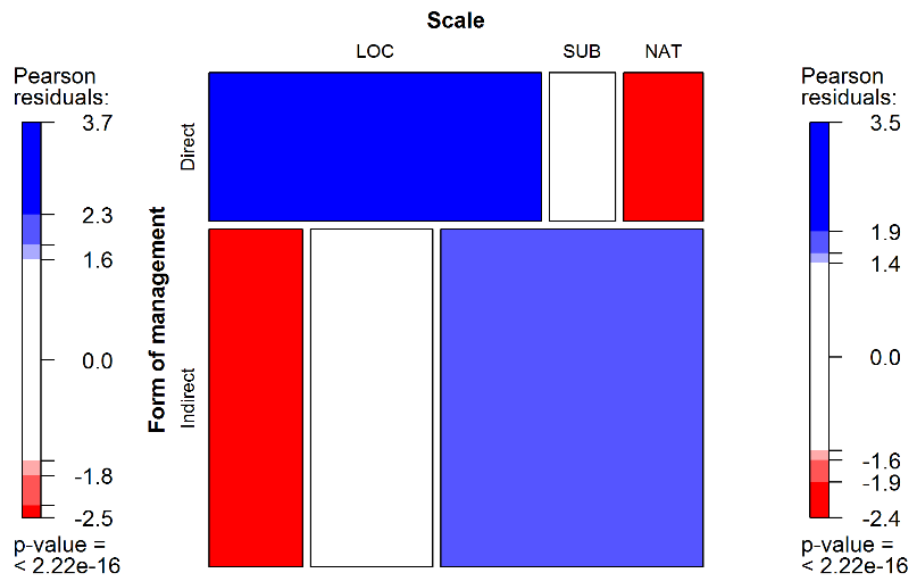

Figure A5.2. Mosaic plots of the frequency of the involvement of different stakeholder groups to different form of ES management (Direct/Indirect management). Each box is associated with a form of management in left list (Direct and Indirect forms of management) and stakeholders groups in top list (type of stakeholder in panel A and scale of influence of stakeholder in panel B). The height of a box is proportional to the number of observations of the corresponding form of management. The width of a box is proportional to the number of stakeholders in each group.

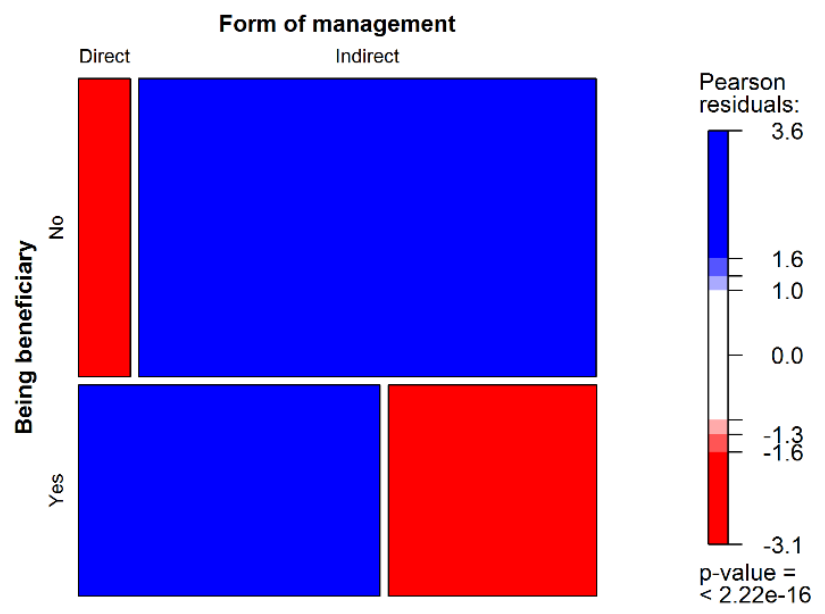

Figure A5.3. Mosaic plot of the frequency of being/not being beneficiary of ES depending on different form of ES management implemented (Direct/Indirect management). Each box is associated with a binary variable in left list (Yes beneficiary, and No beneficiary) and form of management in top list (Direct and Indirect forms of management). The height of a box is proportional to the number of observations for being/not being beneficiary of ES. The width of a box is proportional to the number of stakeholders implementing direct and indirect management. 

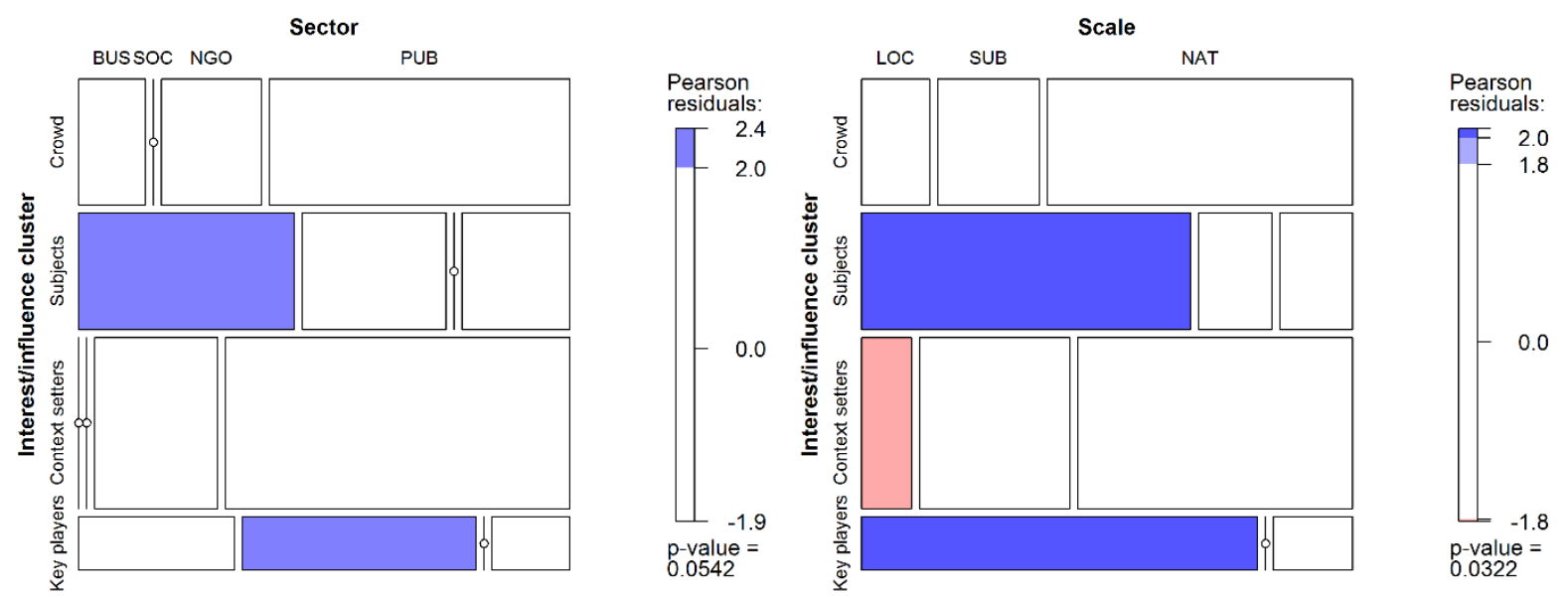

Figure A5.4. Mosaic plots of the frequency of observation of different stakeholder groups into different clusters. Each box is associated with a cluster in left list (Crowd, Subjects, Context setters and Key players) and stakeholders groups in top list (Sector in panel A and Scale of influence in panel B). The height of a box is proportional to the number of stakeholder in each cluster. The width of a box is proportional to the number of stakeholders in each group.

\section{Literature cited}

Friendly, M. 2017. Working with categorical data with R and the vcd and vcdExtra packages.

Meyer, D., A. Zeileis, K. Hornik, F. Gerber, and M. Friendly. 2017. vcd: Visualizing Categorical Data.

R Core Team. 2016. R: A language and environment for statistical computing. R Foundation for Statistical Computing, Vienna, Austria. 


\section{Appendix 6. Stakeholder manual classification.}

The manual classification explained $73 \%$ of total variance. This value was computed using bca function from ade4 package (Dray et al. 2018).

Table A6.1. Characteristics of the clusters.

\begin{tabular}{llll}
\hline Cluster & $\begin{array}{l}\text { Number of } \\
\text { stakeholder }\end{array}$ & $\begin{array}{l}\text { Mean number of ES } \\
\text { benefiting }\end{array}$ & $\begin{array}{l}\text { Mean number of ES } \\
\text { managed }\end{array}$ \\
\hline Crowd & 14 & $0.21 \pm 0.43$ & $1 \pm 0.88$ \\
Subjects & 13 & $3.46 \pm 1.33$ & $1.08 \pm 0.76$ \\
Context setters & 19 & $0.05 \pm 0.23$ & $4.63 \pm 1.54$ \\
Key players & 6 & $4.5 \pm 2.26$ & $4.17 \pm 1.33$ \\
\hline
\end{tabular}

\section{References}

Dray, Stéphane, Anne-Béatrice Dufour, and Jean Thioulouse, with contributions from Thibaut Jombart, Sandrine Pavoine, Jean R. Lobry, Sébastien Ollier, Daniel Borcard, Pierre Legendre, et Stéphanie Bougeard and Aurélie Siberchicot Based on earlier work by Daniel Chessel. 2018. ade4: Analysis of Ecological Data: Exploratory and Euclidean Methods in Environmental Sciences (version 1.7-13). https://CRAN.Rproject.org/package=ade4. 